\title{
CHAPTER 11 ZOMBIES
}

\author{
SALLY MCDONALD HENRY*
}

Chapter 11 is threatened by a corporate zombie apocalypse. In this apocalypse, the courts will be haunted by the remains of Chapter 11 zombies that are neither dead nor alive. Even now, the zombies are appearing throughout the country without having been laid to rest under Chapter 7 or Chapter 11, but also without having been revived under Chapter 11 . The normal burial rules have been disregarded as these half alive/half dead creatures threaten to crowd out the sickly that might be resuscitated.

These zombies often are horribly misshapen. While a normal burial for a corporate bankruptcy case should take place following long-standing rules of statutory and absolute priority that give expected and predictable form to the corpses, these zombies come in all kinds of grotesque forms: those that should be last can be first; those that should be first can be last. There are few rules to control the terror these zombies can inflict on commercial planning and reasonable expectations. They can terrorize both the conservatives who believe in the sanctity of the contract theory of bankruptcy; ${ }^{1}$ and the liberals, who have fought to give workers, ${ }^{2}$ victims of drunken drivers, ${ }^{3}$ children, ${ }^{4}$ and others protection in bankruptcy cases. And not only will they harm the weak that Congress has sought to protect, but, in the form of third-party releases buried into their grotesque forms, they can protect the evil. ${ }^{5}$

These zombies are the recent crop of "structured dismissals" of Chapter 11 cases, and, like in the Night of the Living Dead ${ }^{6}$ they are rising around us. It was not a meteorite, a plague, or a botched scientific experiment that raised these zombies, but history may show it was the global financial crisis of 2007-2008 that set these undead, distorted creatures upon us.

Nothing is as fashionable in the world of Chapter 11 restructurings as are these zombies or "structured dismissals," an undefined term that usually refers to

* Sally McDonald Henry is an associate professor of law at Texas Tech University, and specializes in commercial law, bankruptcy, banking regulation, and related litigation. Professor Henry is a graduate of Duke University and of the New York University School of Law. She wishes to thank her current research assistants Miriam D. Cruz and James David Henderson, and her former research assistant Amber Fly (now clerk to The Honorable Ronald B. King, Chief Judge of the Bankruptcy Court for the Western District of Texas) for their assistance with this article. All errors are hers.

1. For an overview of contract theorists, see Susan Block-Lieb, The Logic and Limits of Contract Bankruptcy, 2001 U. ILL. L. REV. 503 (2001).

2. 11 U.S.C. $\S \S 507(a)(4)-(5)(2012)$.

3. Id. $\S 507(\mathrm{a})(10)$.

4. Id. $\S 507(\mathrm{a})(1)$.

5. See, e.g., Official Comm. of Unsecured Creditors v. CIT Group (In re Jevic Holding Corp.), 787 F.3d 173, 177 (3d Cir. 2015), cert. granted sub nom, Cryzewski v. Jevic Holding Corp., 136 S. Ct. 2514 (2016) [hereinafter, In re Jevic Holding or Jevic].

6. Night of the Living DeAd (21st Century Film Corporation 1990).

http://doi.org/10.18060/4806.1147 
the dismissal of a Chapter 11 case with more than a simple dismissal order. ${ }^{7}$ Instead of the regular dismissal order, a modern structured dismissal order may provide for a number of sophisticated provisions. Examples of these include: the release of claims against non-debtors; claims resolution procedures that differ from those of the bankruptcy rules, oftentimes by shifting the burden of proof; and, in some cases, distributions to claimants that violate the requirements of the Bankruptcy $\mathrm{Code}^{8}$ for Chapter 11 plan distributions. ${ }^{9}$ These extraordinary orders are justified on the theory that they are "necessary"- the shibboleth regularly used to justify paying creditors out of order ${ }^{10}$ - and are the lessor of various evils for a case that is administratively insolvent, or in which the costs of confirming a reorganization plan would drain the estate of its assets so that no distribution to unsecured creditors would be possible. ${ }^{11}$ Because they are neither dead nor alive, are horribly distorted versions of the Code-compliant restructuring plans or Chapter 7 liquidations, and can linger for years after orders have been entered providing for their dismissal, ${ }^{12}$ this Article refers to the orders providing for such dismissals as "Zombie Plans."

Zombie Plans can be simple or complex. The potential complexity of these Zombie Plans is illustrated by In re Coach AM Group Holdings, which involved a motor carrier business. ${ }^{13}$ The dismissal order not only provided for many of the attributes of the classic structured dismissal described above, but even provided for the creation and transfer of assets to a liquidating trust. ${ }^{14}$

7. For other discussions of the emerging trend, see Nan Roberts Eitel et al., Structured Dismissals, or Cases Dismissed Outside of Code's Structure?, 30-MAR AM. BANKR. INST. J. 20 (2011) (article written by employees of the Office of the United States Trustee criticizing structured dismissals); Norman L. Pernick \& G. David Dean, Structured Chapter 11 Dismissals: A Viable and Growing Alternative After Asset Sales, 29-JUN AM. BANKR. INST. J. 1 (2010); Brent Weisenberg, Expediting Chapter 11 Liquidating Debtor's Distribution to Creditors, 31-3 AM. BANKR. INST. J. 36 (2012).

8. 11 U.S.C. $\S \S 101-1532$ (2012).

9. See, e.g., In re Jevic Holding Corp., 787 F.3d at 177.

10. See Capital Factors, Inc. v. Kmart Corp., 291 B.R. 818, 827 (N.D. Ill. 2003) (in seeking to pay over 2000 pre-petition vendors, Kmart had relied on the "doctrine of necessity"), aff' $d$ sub nom. In re Kmart Corp., 359 F.3d 866, 869 (7th Cir. 2004).

11. The efficiency of priority skipping, and the related question of whether it should be encouraged are beyond the scope of this Article, but has been explored elsewhere. See, e. $g$., Douglas G. Baird \& Donald S. Bernstein, Absolute Priority, Valuation Uncertainty, and Reorganization Bargain, 115 Yale L.J. 1930, 1930 (2006); Mark J. Roe \& Frederick Tung, Breaking Bankruptcy Priority: How Rent-Seeking Upends the Creditors'Bargain, 99 VA. L. REV. 1235, 1271 (2013).

12. See, e.g., In re Coach AM Group Holdings Corp., No. 12-10010 (Bankr. D. Del. filed Jan. 3, 2012), ECF. No. 1781 (dismissal order entered May 31, 2013; case was reopened twice after it was first closed, and most recently closed on May 13, 2016).

13. Id.

14. Id. Other cases provide for a trust to hold assets for the sole benefit of unsecured creditors. See, e.g., In re Wickes Holdings LLC and Wickes Furniture Co., No. 08-10212 (after 
At the same time, the term structured dismissal has been used to describe the dismissal of a case with a relatively simple dismissal order. ${ }^{15}$ Such was the case in In re Omaha Standing Bear Pointe, $L L C$, which involved a small condominium property. ${ }^{16}$ In In re Omaha, the property was sold during the case and the debtor commenced adversary proceedings to determine the validity of liens against the property. ${ }^{17}$ Although the dismissal order provided that orders previously entered in the case would remain in effect and that the court would retain jurisdiction of matters relating to the case (the hallmarks of a structured dismissal), the two-page dismissal order was brief and contained few other provisions. ${ }^{18}$

The real horror of some structured dismissal cases is that recently they have been distorting the Bankruptcy Code's priority and equality requirements. In a recent case, the Third Circuit Court of Appeals-the circuit handling appeals from the District of Delaware, where many Chapter 11 cases are filed-approved a case (In re Jevic Holding Corp. ${ }^{19}$ ) involving private equity investors and their bankers who were being sued on fraudulent conveyance claims. ${ }^{20}$ The defendants settled the fraudulent conveyance lawsuit with a deal that squeezed out workers whose claims were entitled to priority, and instead provided for distributions to creditors with a lower legal priority, ${ }^{21}$ which the Third Circuit indicated should be a "rare" 22 occurrence, Certiorari has been granted in the case, and the Supreme Court will rule on the issue in its upcoming term. The question presented is whether the court may approve a pre-plan settlement in a Chapter 11 case that violates the Code's priority rule. ${ }^{23}$

As detailed below, the freeze out of the workers in Jevic appears egregious. Admittedly, the settlement was designed to protect the private equity group that had acquired the failing company (a brief two years before it filed for Chapter 11) in a leveraged buyout, ${ }^{24}$ and the Third Circuit Court of Appeals stressed three times in its decision that this type of resolution of Chapter 11 cases should be "rare." ${ }^{25}$ But are these Zombie Plans that violate the fundamental Chapter 11 protections in fact rare $?^{26}$ In this Article, I share the results of a preliminary examination of structured dismissals entered both before and after Jevic, ${ }^{27}$ and

1393) (Bankr. D. Del. May 11, 2009).

15. Id.

16. A10-8040-TJM, 2011 WL 1004597, at*1 (Bankr. D. Neb. Mar. 17, 2011).

17. Id.

18. Id. at *1-2.

19. 787 F.3d 173 (3d Cir. 2015), cert. granted, 136 S. Ct. 2541 (2016).

20. Id. at 176 .

21. Id. at 176-77.

22. Id. at 175 .

23. Id.

24. Id. at $175,177$.

25. Id. at $175,180,186$.

26. Id. at 186 ("Although this result is likely to be justified only rarely ....").

27. It bears emphasis that the sample of structured dismissal cases I examined was not a scientific sample. First, I located the few reported cases that characterized themselves as having 
conclude that the harms complained of, including the violation of the normal priority rules, are not rare in Chapter 11 structured dismissals. ${ }^{28}$ Indeed, only a few months after the Third Circuit approved the Jevic Zombie Plan, the Third Circuit affirmed another order approving priority-skipping Chapter 11. This case also was a structured dismissal, although the Third Circuit did not acknowledge that the case was in fact another "rare" structured dismissal. ${ }^{29}$ If the Supreme Court affirms the decision of the Third Circuit in Jevic, even on narrow grounds, the long-standing rules of equality of treatment of similar claims, priority for claims we as a nation believe to be deserving of priority, and the Fair and Equitable Rule - cornerstones of debtor-creditor law-may well become a vague memory, as will be further described below. Just as "all" the children in Lake Wobegon, Minnesota, are "above average," ${ }^{30}$ it might be that all structurally dismissed Chapter 11 cases will be "rare" cases in which the long-standing priority and equality rules are ignored. In other words, we could be facing a Chapter 11 Zombie Plan apocalypse.

Part I begins with an explanation of a structured dismissal. ${ }^{31}$ Part II explains the purported statutory basis for a structured dismissal. ${ }^{32}$ Next, Part III describes the cornerstones of fundamental fairness provided for in the Bankruptcy Code:

been "structured dismissals." I also gathered the names of other cases by asking bankruptcy practitioners for the names of cases that were structured dismissals. I then looked at the motions seeking a structured dismissal for the names of other structured dismissal cases, because it is typical for movants to list unreported cases in which similar orders have been entered in their motions when they are seeking unusual relief. I also asked members of a bankruptcy "list serve" of which I am a member to provide the names of any structured dismissal cases of which they were aware. I recognize that examining the cases in this way merely is a beginning in the compilation of anecdotal evidence and merely a first step to refining questions for further study. Should priority skipping structured dismissals survive the Supreme Court's decision in In re Jevic Holding, a more structured examination of the cases should be undertaken. For an article describing a proper investigation of attributes of Chapter 11 cases, see Jay Lawrence Westbrook, Secured Creditor Control and Bankruptcy Sales: An Empirical View, 2015 U. ILL. L. REV. 831 (2015) (reporting on a study of a cross-section from a 2006 sample of Chapter 11 cases).

28. See infra Part III.

29. In re ICL Holding Co., 802 F.3d 547 (3d Cir. 2015). In re ICL Holding Co. was argued on January 14, 2015, and decided on September 14, 2015. In re Jevic was argued the same day, but decided earlier, on May 21, 2015. In both cases, priority claims purposefully were skipped over to provide a distribution to unsecured creditors, as well as payment of counsel for the unsecured creditors. See generally id.; In re Jevic, 787 F.3d 173. Both cases are discussed below.

30. In the popular former radio show Prairie Home Companion, the host, Garrison Keillor, described the mythical town of Lake Wobegon, Minnesota as follows: "[A]ll the women are strong, all the men are good-looking and all the children are above average." Sarah Begley, Garrison Keillor to Say So Long to Lake Wobegon, Time (July 20, 2015), http://time.com/3965277/garrisonkeillor-retiring/ [https://perma.cc/68AU-MWJU].

31. See infra Part I.

32. See infra Part II. 
priorities and equality of distribution. ${ }^{33}$ Part IV describes how, over the years, these principles of priority and equality of distribution have been undermined. ${ }^{34}$ Finally, Part V argues that Jevic is not the only structured dismissal case to ignore the distribution rules of the Bankruptcy Code without even the justifications for previous deviations from the priority and fairness rules. ${ }^{35}$

\section{What is a STRUCTURED Dismissal?}

The term "structured dismissal" is not defined in the Bankruptcy Code, and there is no agreed-upon meaning of the term. As a threshold matter, though, the term structured dismissal usually refers to a case that is dismissed with a proviso in the order that the orders entered previously in the case remain in full force and effect. ${ }^{36}$ A "classic" structured dismissal may not be very extraordinary. One experienced bankruptcy judge recently explained:

structured dismissals occur regularly in this and other bankruptcy courts. Often the parties enter the case on the eve of foreclosure, work out their differences through a sale or giveback of property, and the parties enter an agreement submitted to this court for approval that results in the dismissal of the case. . . If appropriate notice is given and the process is fair and does not illegally or unfairly trample on the rights of parties, the proposal should be approved. ${ }^{37}$

A case that results in a modern structured dismissal is oftentimes commenced with one goal: to expeditiously and economically liquidate the secured creditor's collateral. ${ }^{38}$ Typically, the structured dismissal order is entered after the estate has liquidated all or most of its assets. ${ }^{39}$ In a typical modern case, a secured creditor is paid from the proceeds of the court-ordered sale or sales, professionals are paid in full or in part, and other creditors receive some small distribution. ${ }^{40}$

A Chapter 11 structured dismissal can be consistent with the priority and distribution rules of the Bankruptcy Code. This was apparently the case in In re Buffet Partners, L.P., where the court stressed that the settlement incorporated into the dismissal was consistent with the Fifth Circuit's requirement that all settlements be fair and equitable and the Fifth Circuit's prohibition of settlement schemes that circumvent the protections of the Bankruptcy Code. ${ }^{41}$ Although in that case the structured dismissal order provided for a living-dead post-dismissal

33. See infra Part III.

34. See infra Part IV.

35. See infra Part V.

36. See, e.g., Pernick \& Dean, supra note 7.

37. See, e.g., In re Buffet Partners, L.P., No. 14-30699, 2014 Bankr. LEXIS 3204, at*8

(Bankr. N.D. Tex. July 28, 2014). (Full disclosure: I live in the Fifth Circuit.)

38. Id.

39. See, e.g., In re Jevic Holding Corp., 787 F.3d 173, 176 (3d Cir. 2015).

40. See id. at 177.

41. In re Buffet Partners, 2014 Bankr. LEXIS 3204, at*9. 
retention of jurisdiction, the post-dismissal jurisdiction was limited to the court approving final fee applications and interpreting or implementing orders the court had previously entered. ${ }^{42}$

However, recently structured dismissal orders have provided for several extraordinary provisions that are not contemplated by a typical dismissal of a Chapter 11 case or the "standard" structured dismissals described above. Increasingly common provisions in recent structured dismissal orders may include: (1) the release or "exculpation" of third parties; (2) a settlement or "gift" provision under which claims are paid in an order that is or may be inconsistent with the Bankruptcy Code priorities and rules of equality of distribution; (3) a claims resolution procedure that imposes obligations on creditors that may be more burdensome than those imposed by the Bankruptcy Code and the Bankruptcy Rules; and (4) the retention of jurisdiction of parts of the case after dismissal. ${ }^{43}$

The case of In re Naartjie Custom Kids, Inc. ${ }^{44}$ illustrates many of these attributes. The dismissal order provided:

(1) [A]ll of the Court's orders will remain in full force and effect upon dismissal; (2) the Court shall retain jurisdiction to review and approve professional fees of the Debtor and the Committee; (3) the Court shall retain jurisdiction over any dispute that arises from the interpretation or implementation of the proposed dismissal order; (4) exculpation clauses and general releases shall be included in the dismissal order as contemplated in the Settlement Agreement; and (5) the Debtor and the Committee shall be authorized to make distributions pursuant to the Settlement Agreement. ${ }^{45}$

The settlement agreement that was previously approved by the court divided the estate's assets among various creditors and creditor groups in accordance with their agreement. ${ }^{46}$ In addition, the settlement provided that a distribution in the case would pay administrative claims, "which are subject to the Settlement Budget, and priority claims, not to exceed $\$ 382,000$ " in full. ${ }^{47}$

Depending upon the actual allowed amount of these claims, this provision may have been inconsistent with the normal Chapter 11 plan requirements for distributions to administrative and priority creditors, which requires that, absent any affected creditor's agreement, they be paid in full under the plan. ${ }^{48}$

Another case that illustrates recent structured dismissal provisions is In re

42. $I d$. at $* 4$.

43. In re Jevic Holding Corp., 787 F.3d at 177 (citing In re Strategic Labor, Inc., 467 B.R. 11, 17 n. 10 (Bankr. D. Mass. 2012)).

44. 534 B.R. 416 (Bankr. D. Utah 2015).

45. Id. at 420 .

46. Id. at 419 .

47. Id.

48. 11 U.S.C. § 1129(a)(9) (2012). 
Biolitec. ${ }^{49}$ There, the Chapter 11 trustee moved for a structured dismissal of the case. ${ }^{50}$ Like many structured dismissals, the case provided for an extraordinary release (in this case, of the Chapter 11 trustee).$^{51}$ It also provided for an unusual claims resolution process. Had the court approved the structured dismissal (and it did not), the case would have become a zombie case that was dismissed, but over which the court retained jurisdiction of two adversary proceedings and the claims resolution process. ${ }^{52}$

\section{The Statutory BASIS For StRUCTURED Dismissals}

The usual statutory basis for a structured dismissal is Code $\S 1112,{ }^{53}$ which provides that a court shall convert a Chapter 11 case to a Chapter 7 case or dismiss a case if certain criteria are met. The criteria include "substantial or continuing loss to or diminution of the estate and the absence of a reasonable likelihood of rehabilitation." ${ }^{, 54}$ Whether the case is converted or dismissed depends on what is "in the best interests of creditors and the estate." 55

Even though Code $\S 1112$ is the usual road to dismissal, some structured dismissal cases are also dismissed under Code $\S 305(a) .{ }^{56}$ That Code section provides that " $[\mathrm{t}]$ he court, after notice and a hearing, may dismiss a case under this title ... at any time if-(1) the interests of creditors and the debtor would be better served by such dismissal or suspension."

The Code provision that gives the dismissal "structure" is $\S 349(\mathrm{~b})$, which provides that " $[u] n l e s s$ the court, for cause, orders otherwise, a dismissal ... (2) vacates any order ... and (3) revests the property of the estate in the entity in which such property was vested immediately before the commencement of the case under [Title 11 of the United States Code]."

\section{What Are The Usual Bankruptcy Distribution Rules?}

To better comprehend how the normal distribution rules are affected by many

49. 528 B.R. 261 (Bankr. D. N.J. 2014).

50. Id. at 263 .

51. Id. at $265-66,272$.

52. Id. at 265-66.

53. 11 U.S.C. $§ 1112$ (b)(1) (2012) (providing, in part, that "after notice and a hearing, the court shall convert a case under this chapter to a case under Chapter 7 or dismiss a case under this chapter, whichever is in the best interests of creditors and the estate, for cause unless the court determines that the appointment under section 1104(a) of a trustee or an examiner is in the best interests of creditors and the estate"); see also $\S 305$ (providing for the dismissal of cases that are not subject to review by the courts of appeal or the Supreme Court if "the interests of creditors and the debtor would be better served by such dismissal").

54. 11 U.S.C. $\S 1112(\mathrm{~b})(4)(A)(2012)$.

55. Id. $\S 1112(\mathrm{~b})(1)$.

56. Id. $\S 305$.

57. Id. $\S 305(\mathrm{a})(1)$.

58. Id. $\S 349(\mathrm{~b})(2)-(3)$. 
structured dismissals, I begin by describing the usual distribution schemes, which fit into two categories: the "Normal Required Priority Rules" of Treatment Rules." 60

Cornerstones of bankruptcy practice for years have been these two principles. The Normal Required Priority Rules reflect the principle that claims are paid in the order of priorities that are established by Congress to reflect our societal priorities. ${ }^{61}$ The Equality of Treatment Rule reflects the principle that claims of the same priority generally are paid the same pro rata distribution as a matter of fundamental fairness. ${ }^{62}$ While creditors can waive these core principles (either as a group or individually, depending on the right being waived), these are the foundations on which a plan proponent must shape a reorganization plan. However, these rules are oftentimes violated in a distorted Zombie Plan.

\section{A. The Normal Required Priority Rules}

1. The 507 Priorities.-One component of the Normal Required Priority Rules - which applies in almost all bankruptcy cases - are the priorities set forth in Code $\S 507 .{ }^{63}$ Under that section, which applies in Chapters 7, 11, 12, and $13,{ }^{64}$ top priority goes to domestic support obligations, such as child support. ${ }^{65}$ Second priority goes to administrative expenses, that is, claims that arise during the administration of a Chapter 11 case, such as claims for post-petition rent, claims for post-petition wages, ${ }^{66}$ claims for post-petition taxes ${ }^{67}$ claims for goods purchased post-petition, ${ }^{68}$ and claims of professionals retained in a case ${ }^{69}$ As a matter of statute, administrative expense claims also include a small component of claims that arose pre-petition: claims of vendors for the value of their goods that were received by the debtor within twenty days before the case was commenced. ${ }^{70}$ Third priority goes to what are called "gap claims": claims that arise between the filing of an involuntary bankruptcy petition and a decision whether to grant the petition. ${ }^{71}$ Fourth priority goes to certain employee wages

59. See infra Part III.A.

60. See infra Part III.B.

61. See infra Part III.A.

62. See infra Part III.B.

63. 11 U.S.C. $§ 103$ (a) (2012) ("Except as provided in section 1161 of this title, Chapters 1 , 3 and 5 of this title apply in a case under Chapter $7,11,12$, or 13 of this title ...”).

64. Id. $\S 303(\mathrm{a})$.

65. Id. $\S 507(\mathrm{a})(1)$.

66. Id. $\S 503(\mathrm{~b})(1)(\mathrm{A})(\mathrm{i})$.

67. Id. $\S 503(\mathrm{~b})(1)(\mathrm{B})$.

68. Id. $\S 503(\mathrm{~b})(1)(\mathrm{A})$.

69. Id. $\S \S 503(\mathrm{~b})(2),(4) ; 507(\mathrm{a})(2)$.

70. Id. $\S 503(\mathrm{~b})(9)$ (providing for administrative priority for "the value of any goods received by the debtor within 20 days before the date of commencement of a case under this title in which the goods have been sold to the debtor in the ordinary course of such debtor's business").

71. Id. $\S 507(\mathrm{a})(3) ; \S 502$. 
(up to a cap that is adjusted periodically to reflect inflation), ${ }^{72}$ and this priority has regularly been construed to include state and federal WARN Act claims when the employee is dismissed pre-petition ${ }^{73}$ because these claims are a substitute for wages. Fifth priority belongs to certain employee benefit plans, again up to a cap that is periodically adjusted by the Consumer Price Index for All Urban Consumers. ${ }^{74}$ Other priority claims include certain taxes,${ }^{75}$ some deposits,${ }^{76}$ and claims arising from personal injuries caused by intoxicated drivers. ${ }^{77}$

Congress believes that these priorities are so important that a debtor cannot confirm a reorganization plan unless priority claims are to be paid in full, in cash, unless the holder of the claim agrees to a different treatment. ${ }^{78}$ Thus, unless each individually affected claimholder agrees otherwise, administrative and gap claims must be paid in full, in cash, on the effective date of the debtor's reorganization plan. ${ }^{79}$ Other priority claims must be paid in cash on the effective date of the reorganization plan, unless the class of those claims has accepted the plan, in which case the class must receive cash payments that equal the present value of the claims. ${ }^{80}$

2. The Fair and Equitable Rule.-Chapter 11 has another set of priorities that apply in Chapter 11 cases. These priorities are known as the Fair and Equitable Rule. ${ }^{81}$ Specifically, the Code requires that a plan must be "fair and equitable" as to classes of claims that have not accepted the plan. ${ }^{82}$ Fair and equitable includes the concept that secured claims, unsecured claims, and interests must be treated in accordance with a specific priority of payment, which oftentimes is referred to as the "Absolute Priority Rule." 83 These priorities, set forth in Code $\S 1129$ (b), provide that secured claims must be paid in full over time before unsecured

72. Id. § 507(a)(4); Id. § 104(a).

73. If the employee is dismissed post-petition, the employee may be entitled to an administrative claim arising from some or all of the debtor's severance pay obligations. See, e.g., Former Emps. of Builders Square Retail Stores v. Hechinger Inv. Co. of Del. (In re Hechinger Inv. Co. of Del.), 298 F.3d 219, 224 (3d Cir. 2002).

74. 11 U.S.C. $\S \S 507(a)(5)(2012) ; 104(a)$.

75. $I d . \S 507(\mathrm{a})(8)$.

76. $I d . \S 507(\mathrm{a})(7)$.

77. Id. $\S 507(\mathrm{a})(10)$.

78. See id. $\S 1129(\mathrm{a})(9)$.

79. Id. $\S 1129(\mathrm{a})(9)(\mathrm{A})$.

80. Id. $\S 1129(\mathrm{a})(9)(\mathrm{B})$. The treatment of priority claims of governmental units is a bit more complicated. Id. $\S 1129(\mathrm{a})(9)(\mathrm{C})$.

81. See Pamela Foohey, Chapter 11 Reorganization and the Fair and Equitable Standard: How the Absolute Priority Rule Applies to All Nonprofit Entities, 86 ST. JOHN's L. REv. 31, 33-34 (2012).

82. 11 U.S.C. § 1129(b)(1) (2012). See generally Bruce A. Markell, A New Perspective on Unfair Discrimination in Chapter 11, 72 AM. BANKR. L. J. 227, 228-29 (1999) (describing the "Fair and Equitable Rule" as being the "vertical priority").

83. Because the term "Absolute Priority Rule" is not defined in the Bankruptcy Code, cases use it inconsistently, and thus I prefer to focus on the Code's "fair and equitable" language. 
claims are paid ${ }^{84}$ and unsecured claims must be paid in full over time before equity holders are paid.$^{85}$ Classes of claims can waive this priority through voting for the plan in the requisite amounts (for unsecured claims, more than one-half in number and two-thirds in amount voting $;{ }^{86}$ for equity holders, more than twothirds in amount voting) ${ }^{87}$ Moreover, parties can contract among themselves for subordination, and those contracts are enforceable notwithstanding the statutory priorities. ${ }^{88}$ In addition, particular claims can be subordinated as a matter of law under equitable principles (most often when the claimholder is guilty of wrongdoing). ${ }^{89}$ That being said, the Supreme Court has repeatedly failed to approve any non-codified exceptions to the Fair and Equitable Rules. ${ }^{90}$

3. The Back Door Best Interests Priority.-The Code includes one other "back door" priority requirement: what is popularly called the "best interests test." ${ }^{\prime 11}$ This priority is implicit in Code $\S 1129(\mathrm{a})(7)$, which provides that each entity whose claim is "impaired" (affected in any way by the plan) $)^{92}$ must receive as much as it would receive in a Chapter 7 liquidation. ${ }^{93}$ Because 11 U.S.C. $\S$ 726, which applies in Chapter 7 liquidations, requires a specific waterfall of secured claims, priority claims, unsecured claims, and equity interests in Chapter 7 cases, Code $\S 1129(\mathrm{a})(7)$ also reinforces the priority rules. ${ }^{94}$ Of course, if instead of being structurally dismissed, a Chapter 11 case were converted to Chapter 7, any distribution in Chapter 7 would have to comply strictly with the priorities of Code $\S 726$.

Together, the Fair and Equitable Rule (which technically applies only in connection with the confirmation of a reorganization plan); the Back Door Best Interests Priority (which, again, technically applies only in connection with the confirmation of a reorganization plan) and the Code $\S 507$ Priorities (which, by 507 's terms, establishes priorities that apply regardless of whether a plan is being

84. 11 U.S.C. § 1129(b)(2)(A) (2012). Secured claimholders can credit bid for their collateral or receive the "indubitable equivalent" of their claims, which might be some or all of their collateral or substitute collateral, provided their claims are paid in full.

85. Id. $\S 1129(\mathrm{~b})(2)(\mathrm{B})$.

86. Id. $\S 1126(\mathrm{c})$.

87. Id. $\S 1126(\mathrm{~d})$.

88. Id. $\S 510(\mathrm{a})$.

89. Id.; see generally United States v. Noland, 517 U.S. 535 (1996) (discussing cases requiring wrongdoing for equitable subordination).

90. See Bank of Am. Nat'l Trust \& Sav. Ass'n. v. 203 N. LaSalle St. P'ship, 526 U.S. 434 (1999) (equity holders could not retain interest in debtor when senior creditors were not being paid in full because current equity holders had the only opportunity to retain interest); Norwest Bank Worthington v. Ahlers, 485 U.S. 197 (1988) (contribution of labor, experience, and expertise is not adequate new value to allow for exception to absolute priority rule in 11 U.S.C. § 1129(b)).

91. See Jonathan Hicks, Foxes Guarding the Henhouse: The Modern Best Interests of Creditors Tests in Chapter 11 Reorganizations, 5 NEV. L.J. 820, 821 (2005).

92. 11 U.S.C. $\S 1124$ (2012).

93. Id. $\S 1129(\mathrm{a})(7)(\mathrm{A})(\mathrm{ii})$.

94. See generally id. $\S 726$. 
confirmed $^{95}$ ) are referred to herein as The Normal Priority Rules.

4. The Narrow Exception to Adjusting Priorities.-Throughout the Code, therefore, Congress repeatedly directs that Chapter 11 cases follow specific priority rules.$^{96}$ Compared to these multiple priority mandates of the Code, there is, absent agreement of the affected parties, just one minor statutory exception to the priority rules in limited circumstances: Code $\S 510(\mathrm{c}),{ }^{97}$ which provides that particular claims can be subordinated on equitable grounds. This provision has historically been construed strictly, given the importance of the Normal Priority Rules to the bankruptcy laws. ${ }^{98}$ For example, in United States v. Noland, ${ }^{99}$ the Supreme Court held that claims for penalties arising from taxes could not be categorically subordinated because Code $\S 507$ specifically provided those claims were entitled to priority. ${ }^{100}$

There is no statutory provision in Chapter 11 (except Code $\S 510$ ) that allows these priority rules to be disregarded. ${ }^{101}$ That being said, litigants have argued that there are non-statutory exceptions ${ }^{102}$ to these priority rules. One such purported non-statutory exception is the so-called "New Value" exception, under which equity can retain an interest in the debtor even though prior claims or interests are not being paid in full so long as equity contributes a sufficient amount of value to the estate. ${ }^{103}$ Despite this rule having been recognized in dicta by the Supreme Court in a pre-Code case, ${ }^{104}$ the Supreme Court has never endorsed it. The two times the Supreme Court was confronted with the issue of whether the New Value exception to the Fair and Equitable rules survived the enactment of the Bankruptcy Code, the Court declined to determine the issue but held that, even if there were a New Value exception, the criteria had not been met in the cases

95. Id. § 103(a).

96. See, e.g., 11 U.S.C. $\S \S 507,724,726,1115,1122,1129,1171$ (2012).

97. 11 U.S.C. $\S 510(c)(1)$ (2012) provides that "the court may[,] . . under principles of equitable subordination, subordinate for purposes of distribution all or part of an allowed claim." Parties can also agree among themselves to subordinate claims, 11 U.S.C. $\S 510$ (a), but that agreement, rather than the operation of the Code, is what is responsible for altering priorities.

98. See, e.g., United States v. Noland, 517 U.S. 535 (1996) (given the importance of specific statutory priorities adopted by Congress, tax penalties cannot be categorically subordinated under 11 U.S.C. $\S 510(\mathrm{c}))$. For an earlier discussion of the narrow scope of equitable subordination, see Andrew DeNatale \& Prudence B. Abram, The Doctrine of Equitable Subordination as Applied to Nonmanagement Creditors, 40 Bus. LAW 417, 421 (1985); see also In re Mobile Steel Co., 563 F.2d 692, 700 (5th Cir. 1977) (importance of "inequitable conduct" to claim for equitable subordination).

99. 517 U.S. 535 (1996).

100. $I d$. at 536 .

101. See generally 11 U.S.C. $\S \S 101-1532$ (2012).

102. Litigants will sometimes categorize these "exceptions" as being refinements or clarifications rather than exceptions.

103. Dish Network Corp. v. DBSD N. Am., Inc. (In re DBSD N. Am., Inc.), 634 F.3d 79, 93100 (2d Cir. 2011).

104. Case v. L.A. Lumber Prods. Co., 308 U.S. 106, 121-22 (1939). 
before it. ${ }^{105}$ Thus, for example, it refused to allow a farming couple to retain their property through "sweat equity" when all unsecured claims would not be paid in full. ${ }^{106}$

\section{B. Equality of Treatment Rule}

There is one other concept that is important in bankruptcy distributions, which I will call the Equality of Treatment Rule.

The Equality of Treatment Rule is the principle that claims of the same priority generally should be paid pro rata. For example, to receive equality of treatment, all holders of pre-petition wage claims should receive the same percentage distribution on their claims, and not receive a different percentage payout based upon the preferences of other creditors or equity holders. Similarly, the Equality of Treatment Rule requires that all administrative creditors receive the same percentage payout on their claims. ${ }^{107}$ In fact, the Code never specifically provides for pari passu payments for non-priority ${ }^{108}$ claims of the same priority in all Chapter 11 cases, but it does provide that all claims that are classified together for the purpose of voting on a reorganization plan must be paid the same amount on their claims unless the claimants agree to less favorable treatment. ${ }^{109}$ The Code also provides that all claims that are classified together must be similar. ${ }^{110}$

Although a common classification of claims would be to have all secured claims secured by the same collateral classified together, all unsecured claims of the same priority classified together, and all equity claims of the same priority classified together, in some cases, claims with the same priority can be can be separately classified for voting purposes. ${ }^{11}$ If the separate classification is

105. See supra note 90.

106. Norwest Bank Worthington v. Ahlers, 485 U.S. 197, 198 (1988).

107. See 11 U.S.C. $\S 1129$ (b) (2012).

108. Although the Code does not require that administrative and priority claims be paid pro rata, it requires that, absent consent by the affected creditor, they be paid in full as a condition to confirmation of a reorganization plan, so the Code provides a result that is identical to a provision requiring equal treatment. $I d$. $\$ 1129(\mathrm{a})(9)$.

109. Id. $\S 1123(\mathrm{a})(4)$ (a plan shall "provide the same treatment for each claim or interest of a particular class, unless the holder of a particular claim or interest agrees to a less favorable treatment of such particular claim or interest").

110. Id. § 1122(a) ("Except [for a convenience class], a plan may place a claim or an interest in a particular class only if such claim or interest is substantially similar to the other claims or interests of such class.").

111. See, e.g., Class Five New Claimants v. Dow Corning Corp. (In re Dow Corning Corp.), 280 F.3d 648, 662-63 (6th Cir. 2002) (separate classification for foreign claimants based on facts that were not clearly erroneous); In re Unbreakable Nation Co., 437 B.R. 189, 200 (Bankr. E.D. Pa. 2010) (approving separate classification of claims that arose from claimant having been a shareholder in debtor's predecessor from ordinary trade claims); In re EBP, Inc., 172 B.R. 241, 244 (Bankr. N.D. Ohio 1994) (approving separate classification of tort claim that represented seventy 
appropriate and not designed to manipulate the rules relating to acceptance of a plan, most courts hold there is no absolute bar to the claims of the same priority that have been placed in different classes receiving a different percentage distribution, ${ }^{112}$ although most cases have not approved different pro rata distributions. ${ }^{113}$ That being said, if a distribution scheme such as this is not approved by an affected class by the required numbers and amounts, the plan proponent will have to make a strong showing to establish that the disparate treatment is justified and does not "discriminate unfairly." "114

With respect to impaired classes of claims or interests that are not in the same class, the Equality of Treatment Rule is set forth in part in Code $\S 1129(\mathrm{~b})$, which provides that "the court ... shall confirm the plan [notwithstanding the failure of a class to accept the plan] if the plan does not discriminate unfairly." ${ }^{115}$ This section only applies to an impaired class that has not voted for the plan in the required numbers and amounts. ${ }^{116}$

The term "discriminate unfairly" is not defined in the Code, and courts have debated how to define it. On its face, it allows for some discrimination. However, does that mean different pro rata distributions for creditors of the same rank are acceptable, or does it mean something less problematic, such as different means of liquidation of the claim, different timing for different types of claims, or different modes of payment? ${ }^{117}$ Generally, courts take the view that unless the discrimination has a reasonable rationale and is necessary for the reorganization, a plan may not separate groups of claimants holding claims of identical priority into different classes and provide materially different treatment for those classes. ${ }^{118}$ Courts also compare the payouts among the different classes to

percent of the debt).

112. See, e.g., Heartland Fed. Sav. \& Loan Ass'n v. Briscoe Enters. (In re Briscoe Enters.), 994 F.2d 1160, 1167 (5th Cir. 1993) ("[T] hou shalt not classify similar claims differently in order to gerrymander an affirmative vote on a reorganization plan.") (allowing for separate classification of cities' claim), citing Phoenix Mut. Life Ins. Co. v. Greystone III Joint Venture (In re Greystone), 948 F.2d 134 (5th Cir. 1991).

113. Markell, supra note 82, at 240.

114. See, e.g., Liberty Nat'l Enters. v. Ambanc La Mesa Ltd. P'ship (In re Ambanc La Mesa Ltd. P'ship), 115 F.3d 650, 656 (9th Cir. 1997) (setting forth four-part test for determining whether discrimination is fair); Markell, supra note 82 at 250 (rejecting Ambanc four-part test and crafting rebuttable presumption test for determining if discrimination is fair).

115. 11 U.S.C. $\$ 1129$ (b)(1) (2012).

116. Id. $\S 1129$ (b).

117. See generally Markell, supra note 82. Professor Markell refers to the requirement that a non-consensual plan not discriminate unfairly as being a "horizontal limit on nonconsensual confirmation." Id. at 227.

118. In re Armstrong World Indus., Inc., 348 B.R. 111 (D. Del. 2006) (separate classification of tort claims and claims relating to asbestos was appropriate when the two classes would receive approximately the same distribution); In re Resorts Int'l, Inc., 145 B.R. 412, 481 (Bankr. D. N.J. 1990) (approving separate classification of subordinated claims). Courts tend to apply either the test articulated in Ambanc or the Markell test. See In re Ambanc La Mesa Ltd. P'ship, 115 F.3d at 
determine if the difference is material or appropriately justified. ${ }^{119}$

In addition to the prohibition against unfair discrimination in Code $\S 1129$ (b), the Code also suggests (through the best interests of creditors "back door") that all non-consenting creditors should be paid pro rata. ${ }^{120}$ Recall, Code $\S 1129$ (a)(7), which applies whether or not a class accepts the plan, provides that any individual impaired ${ }^{121}$ creditor that does not vote for the plan must receive as much as it would in a Chapter 7 liquidation. ${ }^{122}$ Unlike Code $\S 1129$ (b), Code $\S$ 726 leaves no room for considering whether the discrimination is fair or unfair: It plainly provides, by incorporating Code $\S 726$, that entities of equal priority will benefit from the same position on the payment waterfall. ${ }^{123}$ Of course, because a hypothetical liquidation will bear its own costs, Code $\$ 1129(a)(7)$ will not necessarily ensure the exact same distribution to every dissenting creditor that it would receive in a Chapter 7 case. However, in a case such as a structured dismissal, in which the assets have been liquidated before the distributions are determined, and liquidation costs and Chapter 7 professional and trustees are not considered in the calculation, this back door equal treatment rule could have more relevance. It only "could," have more relevance because by its terms the Best Interests Test with its hypothetical liquidation only applies to plan confirmation, unlike Code section 507, which on its face is not limited in application to Chapter 11 cases in which a reorganization plan is confirmed.

Despite the importance of these priority and equality rules, the Code nowhere specifically states that if claims are paid when a case is dismissed, they must be paid in accordance with the Fair and Equitable Rule or the Best Interests Test. ${ }^{124}$ The Code also does not require that distributions made in connection with a dismissal not discriminate unfairly. The Code does explicitly provide, however, that the priorities of Code $\S 507$ apply in Chapter 11 subject only to equitable

656; Markell, supra note 82, at 250.

119. Compare In re Tribune Co., 464 B.R. 126 (Bankr. D. Del. 2011) (less than ten percent difference in payout for dissenting class was not unfair discrimination); In re Unbreakable Nation Co, 437 B.R. 189, 202 (Bankr. E.D. Pa. 2010) (difference in distribution between two classes was immaterial; accordingly, discrimination was not unfair); In re Greate Bay Hotel \& Casino, Inc., 251 B.R. 213, 231 (Bankr. D. N.J. 2000) (difference between eighty percent and seventy-six percent payout was immaterial; discrimination not unfair), with In re Crosscreek Apartments, Ltd., 213 B.R. 521, 537-38 (Bankr. E.D. Tenn. 1997) (fifty percent difference in recovery between classes was unfair discrimination) and In re Cranberry Hill Assocs., L.P., 150 B.R. 289, 290-91 (Bankr. D. Mass. 1993) (fifty percent difference in recovery between classes was unfair discrimination).

120. 11 U.S.C. $\S 726$ (b) (2012).

121. "Impairment" is broadly described in 11 U.S.C. $\S 1124$ (2012), and includes any alteration of the legal rights of the holder of a claim.

122. 11 U.S.C. $\S 1129(\mathrm{a})(7)$ (2012).

123. Id. $\S 726$ (b) (describing the priority between the claims, except in limited cases involving the conversion of cases: "Payment ... shall be made pro rata among claims of the kind specified in each such particular paragraph ....").

124. See generally id. $\S \S 101-1532$. 
subordination principles. ${ }^{125}$ Nevertheless, courts have blocked schemes designed to abrogate protections that creditors receive during the plan process, and therefore will not allow the imposition of a "sub rosa plan" on creditors as part of a binding deal that is not entered into with plan protections. ${ }^{126}$ Many courts have not, however, imposed the same limitation on structured dismissals. ${ }^{127}$

\section{The Continuing ERosion on the Normal Priority AND EQUALITY RULES}

Zombie Plan settlements should be recognized as an additional step in the evolution away from the Normal Priority and Equality of Treatment Rules, which have been increasingly disregarded without either the approval of the Supreme Court or amendments to the Bankruptcy Code. ${ }^{128}$ Described below are some of the key ways in which these Normal Priority Rules and Equality of Treatment Rules have been undermined over the years. Many of these violations of the Normal Priority and Equality of Treatment Rules are components of Zombie Plans.

\section{A. First Day Orders}

A common way in which the Normal Priority and Equality of Treatment Rules are violated is through the entry of extraordinary orders at the beginning of a bankruptcy case that provides for either the immediate payment or the setting aside of funds for claims even though there is no proof that all superior or equal claims will be paid in full. The most common - and probably most necessary-of these orders is the employee order, which provides that outstanding pre-petition claims for wages and employee benefits will be paid in full or in part. ${ }^{129}$ These

125. Id. § 103(a).

126. See, e.g., Pension Benefit Guar. Corp. v. Braniff Airways, Inc. (In re Braniff Airways, Inc.), 700 F.2d 935, 940 (5th Cir. 1983) (sale of estate assets out of the ordinary course of business under 11 U.S.C. $\S 363$ (b) that incorporated settlements was sub rosa plan and could not be approved because it deprived creditors of the protections of the plan process).

127. But see In re Olympic 1491 Elm Assocs., No. 16-30130, 2016 Bankr. LEXIS 3164 (Bankr. N.D. Tex. Aug. 26, 2016) (approving structured dismissal that was not a sub rosa plan); In re Biolitec, Inc., 528 B.R. 261, 272 (Bankr. D. N.J. 2014) (structured dismissal could not be approved because it was similar to a sub rosa plan in which creditors were denied confirmation protections).

128. See generally In re World Health Alts., Inc., 344 B.R. 291 (Bankr. D. Del. 2006) (approving settlement between creditors' committee and secured creditor in Chapter 11 case that was anticipated to be converted to a Chapter 7 case; settlement skipped priority creditors to earmark proceeds of settlement for general unsecured creditors even though estate causes of action were being settled).

129. See George W. Kuney, Hijacking Chapter 11, 21 Emory Bankr. Dev. J. 19, 75-76 (2004). Because an employee may be paid for work completed weeks before her paycheck was issued, even if she is to be due to be paid post-petition, the wages can constitute pre-petition wages. 11 U.S.C. § 101(10) (2012) (defining creditor). 
orders often are limited to amounts that would be no greater than the amount of the claims that is entitled to Code $\S 507(\mathrm{a})(4)$ and 507(a)(5) priorities, although sometimes they are not so limited. If the employee first day order is limited to the priority amount, and if a plan is confirmed and becomes effective, the employee order shifts timing of the payment but not priorities, because all priority claims have to be paid in full for a plan to be confirmed. ${ }^{130}$

Another set of claims that are oftentimes paid "out of order" at the inception of a case are tax claims, which may be claims on which officers and directors of the debtor are jointly liable, such as claims for withholding taxes. ${ }^{131}$ Again, these claims are themselves often entitled to priority, either through the Code's priority scheme or under a legal theory that the taxes are being held in trust by the estate. ${ }^{132}$ That being noted, these claims are regularly allowed to be paid without a careful legal analysis of the priority and trust fund issues relating to each type of tax claim.

It is understandable that restructuring cases could fail early on if employees or taxes for which officers are potentially liable are not paid. Not all extraordinary first day orders, however, are so compelling. The most problematic of the orders providing for the payment of pre-petition claims that are paid in first day orders are claims of vendors or suppliers that the debtor believes to be "critical vendors." " ${ }^{\prime 33}$ Although the Bankruptcy Code provides for a priority for the seller of goods that the debtor receives within twenty days before it files its petition, ${ }^{134}$ that priority does not cover services, may not reach back as far as the debtor would like, and is only required to be paid on the effective date of a reorganization plan. ${ }^{135}$ Accordingly, if the debtor has cash-or if the secured creditor hopes to sell the assets of the debtor as a going concern and it is willing to make cash available for the purpose - the debtor will seek one of these orders, which many courts grant.

In theory, a typical debtor could avoid having to seek the extraordinary relief of a critical vendor order by carefully managing its payables pre-petition in the period when it is facing financial difficulty and preparing to file its Chapter 11 case. ${ }^{136}$ Vendors could be paid prepetition in the ordinary course of business, for

130. 11 U.S.C. $\S 1129(a)(9)(2012)$.

131. Id. $\S 507(\mathrm{a})(8)$.

132. $I d$.

133. See Christopher D. Hunt, Not-So-Critical Vendors: Redefining Critical Vendor Orders, 93 KY. L.J. 915 (2004/2005).

134. 11 U.S.C. $\S 503(b)(9)$ (2012) (providing for an administrative priority for "the value of any goods received by the debtor within 20 days before the date of commencement of a case under this title in which the goods have been sold to the debtor in the ordinary course of such debtor's business").

135. Id. $\S 1129(\mathrm{a})(9)$.

136. Assuming the debtor has enough cash, bankruptcy lawyers typically try very hard to get all employees on direct deposit for the payment of their salaries and benefits to protect those creditors from hardship as a result of the Chapter 11 filing. 
example. ${ }^{137}$ Similarly, other trade creditors could be pre-paid for their goods. ${ }^{138}$ However, neither of these, or other potential strategies for dealing with vendors, may be a practical resolution of the potential problems. This is because the debtor may be short of cash and the secured creditor may not be willing to lend the debtor enough money pre-petition to allow for C.O.D. deliveries, prepayments, etc. In fact, the secured creditor may only be willing to lend more money postpetition because the secured creditor may be able to charge a higher interest rate, charge various additional fees, and perhaps obtain other benefits (such as a strict limitation on the time for entities to assert claims against the lender) if it makes cash available to the debtor through a post-petition loan, rather than through greater pre-petition availability. ${ }^{139}$

Although the first day orders, including the critical vendor orders, are routinely granted, the statutory basis for some of the orders is unclear or debatable. Sometimes, the orders are justified on the basis of a pre-Code doctrine: the "doctrine of necessity." 140 This theory, which developed during the heyday of railroad reorganizations, allowed certain payments to be made that were deemed to be critical to the continued operation of the railroads. ${ }^{141}$ Its application is illustrated in In re Lehigh \& New England Railway Co. ${ }^{142}$ in which the Third Circuit Court of Appeals allowed the payment to creditors outside of the normal priority schemes because those payments would "facilitate the continued operation of the railroad." ${ }^{\prime 43}$ In the pre-Code era, the doctrine was even extended to non-railroad cases, as when the Second Circuit Court of Appeals allowed for priority for certain suppliers whose goods were necessary to ensure the debtor's continued operation. ${ }^{144}$

The current statutory "hook" for invoking the doctrine of necessity is Code $\S 105,{ }^{145}$ which provides that the court may enter any order necessary in the case. Some courts accept that rationale, ${ }^{146}$ but others suggest that Code $\S 363(b)(1)$, which allows a debtor to use property of the estate "in the ordinary course of business" after a notice and a hearing, is the more appropriate statutory basis for such orders. ${ }^{147}$ Moreover, the Supreme Court has stressed in a case reinforcing the

137. See 11 U.S.C. $\S 547(c)(2)(2012)$.

138. See id. §503(b)(9).

139. See Kuney, supra note 129 (describing common elements of debtor-in-possession financing).

140. Hunt, supra note 133, at 917-18; Alan N. Resnick, The Future of the Doctrine of Necessity and Critical Vendor Payments in Chapter 11 Cases, 47 B.C. L. Rev. 183, 186 (2005).

141. Resnick, supra note 140, at 186, 193.

142. 657 F.2d 570 (3d Cir. 1981).

143. Id. at 581 .

144. Dudley v. Mealey, 147 F.2d 268, 271 (2d Cir. 1945).

145. 11 U.S.C. $\$ 105$ (a) (2012) ("The court may issue any order, process, or judgment that is necessary or appropriate to carry out the provisions of this title.").

146. See, e.g., Bessette v. Avco Fin. Servs., Inc., 230 F.3d 439, $444-45$ (1st Cir. 2000).

147. See, e.g., In re Kmart Corp., 359 F.3d 866, 872-73 (7th Cir. 2004). 
importance of the Normal Priority Rules ${ }^{148}$ that "whatever equitable powers remain in the bankruptcy courts must and can only be exercised within the confines of the Bankruptcy Code." 149

Despite the variety of critical vendor orders that are entered, ${ }^{150}$ they have never been blessed by the circuit courts. ${ }^{151}$ Rather, the only circuit court to consider the propriety of a critical vendor order-the Seventh Circuit Court of Appeals in its determination on an appeal from a critical vendor order in In re Kmart Corp. ${ }^{152}$-ruled that, even if there were a legal basis for these extraordinary "critical vendor" payments after enactment of the 1978 Bankruptcy Code, the debtor had failed to prove that the critical vendor order entered in that case was in fact necessary. ${ }^{153}$ There, the debtor had proposed paying about $\$ 300$ million to roughly 2330 suppliers. ${ }^{154}$ The appellate court gave no weight to the doctrine of necessity or the vague words of 11 U.S.C. § 105(a). A doctrine of necessity, the circuit court explained, "is just a fancy name for a power to depart from the Code" 155 and the power in Code $\S 105$ "is one to implement rather than override" 156 the Code. The court was convinced that the vague equitable doctrine that pre-dated the codification of the Bankruptcy Code could not have survived the careful overhaul of the law that went into effect in $1979 .{ }^{157}$ The circuit court explained:

[The doctrine of necessity cases] predate the first general effort at codification, the Bankruptcy Act of 1898. Today the Bankruptcy Code of 1978 supplies the rules. Congress did not in terms scuttle old common-law doctrines, because it did not need to; the Act curtailed, and then the Code replaced, the entire apparatus. Answers to contemporary issues must be found within the Code (or legislative halls). ${ }^{158}$

The Seventh Circuit suggested that the record supporting a critical vendor order would have to meet this criterion: "[P]referential payments to a class of creditors are proper only if the record shows the prospect of benefit to the other creditors. This record does not, so the critical-vendors order cannot stand."159 "Disfavored creditors," the court explained, should be better off or at least no

148. Norwest Bank Worthington v. Ahlers, 485 U.S. 197, 206 (1988).

149. Id.

150. See, e.g., In re Just for Feet, Inc., 242 B.R. 821 (D. Del. 1999); In re Jeans.com, Inc., 502 B.R. 250 (Bankr. D. P.R. 2013); In re Wehrenberg, Inc., 260 B.R. 468 (Bankr. E.D. Mo. 2001); In re Ionosphere Clubs, Inc., 98 B.R. 174 (Bankr. S.D.N.Y. 1989).

151. See generally Hunt, supra note 133; Resnick, supra note 140.

152. 359 F.3d 866 (7th Cir. 2004).

153. Id. at 874 .

154. Id. at 869 .

155. Id. at 871 .

156. Id.

157. $I d$.

158. Id.

159. Id. at 874 . 
worse off, as a result of preferences. ${ }^{160}$

The justification for the critical vendor order is typically that a reorganization will not be possible if critically important vendors are not paid. ${ }^{161}$ These vendors could be foreign vendors (who may be able to attach the debtor's property located in a foreign jurisdiction); ${ }^{162}$ small operations that would go bankrupt themselves if they are not paid, ${ }^{163}$ and "sole source" suppliers. ${ }^{164}$ Despite the representations that these vendors are "special situations," in many cases the critical vendor orders can provide for substantial payments in total, as is evident from Kmart. ${ }^{165}$ In any event, despite the absence of circuit-level approval of the practice under the Bankruptcy Code, numerous courts continue to enter critical vendor orders. ${ }^{166}$

\section{B. Carve Outs}

Another way in which the Equality of Treatment Rule potentially is violated in Chapter 11 cases is through a "carve out." ${ }^{.67}$ Again, the term "carve out" is undefined in the Code, but is ubiquitous in Chapter 11 cases. ${ }^{168}$

A carve out is a provision in a financing order, ${ }^{169}$ or sometimes in an order allowing the debtor to use cash collateral, ${ }^{170}$ providing that, even if all the

160. Id. at 868 .

161. Id. at 868-69.

162. Collier Guide to Chapter 11 \ 20.03 (2015).

163. Id.

164. Id.

165. In re Kmart Corp., 359 F.3d at 874.

166. See, e.g., In re Just for Feet, Inc., 242 B.R. 821, 826 (D. Del. 1999) (providing for payments to vendors that were essential to the debtor's survival); Osborne v. Howell Elec. Motors (In re Fultonville Metal Polish Co.), 330 B.R. 305, 313 (Bankr. M.D. Fla. 2005) (setting forth threepart test that must be met to allow for payment of critical vendors); In re Tropical Sportswear Int'1 Corp., 320 B.R. 15, 17 (Bankr. M.D. Fla. 2005); In re C.A.F. Binders Inc., 199 B.R. 828, 834-35 (Bankr. S.D.N.Y. 1996); In re Ionosphere Clubs, Inc., 98 B.R. 174, 175-76 (Bankr. S.D.N.Y. 1989) (allowing preferential payment of claims that were shown to be essential to the preservation of the debtor). But see Scharffenberger v. Billmire (In re Allegheny Health, Educ. \& Research Found.), 313 B.R. 673, 678 (Bankr. W.D. Pa. 2004) (not approving critical vendor payments because the proponents had not made the requisite showing of "extraordinary circumstances"). See generally Joseph Gilday, "Critical" Error: Why Essential Vendor Payments Violate the Bankruptcy Code, 11 Am. BAnkr. Inst. L. Rev. 411, 424, 443 (2003); Mark. A. McDermott, Critical Vendor and Related Orders: Kmart and the Bankruptcy Abuse Prevention and Consumer Protection Act of 2005, 14 Am. Bankr. Inst. L. ReV. 409 (2006); Alan N. Resnick, The Future of the Doctrine of Necessity and Critical-Vendor Payments in Chapter 11 Cases, 47 B.C.L.REV. 183, 203-05 (2005).

167. See generally Richard B. Levin, Almost All You Ever Wanted to Know About Carve Outs, 76 AM. BANKR. L.J. 445, 449 (2002).

168. Id.

169. "Financing order" refers to an order allowing a debtor to borrow money post-petition. See 11 U.S.C. $\S 364(c)$ (2012).

170. Absent consent of the secured creditor, a debtor cannot use cash collateral without court 
debtors' assets are subject to security interests, and even if the secured creditor or creditors are undersecured, certain proceeds from the creditors' collateral will be made available to pay designated administrative professional fees (the "Favored Professionals Fees"). ${ }^{171}$ The carve outs come in many varieties, but it is very common for there to be a proviso that certain professional fees may be paid to the extent approved by the court unless the debtor defaults on its loan from the creditor or on its obligations under an order approving the use of cash collateral, and after default, a certain amount of money will be available in any event to pay Favored Professional Fees. ${ }^{172}$ The amount of the carve out will typically be proportionate to the size of the case. ${ }^{173}$

Carve outs are justified on the theory that otherwise professionals would be reluctant to undertake bankruptcy representations. ${ }^{174} \mathrm{~A}$ first principle of bankruptcy is the entity with the highest priority is the secured creditor who is entitled to be paid out of his collateral even if no other creditor receives a distribution. ${ }^{175}$ Of course, every administrative creditor bears the risk that an estate will be administratively insolvent and that it will not be paid. ${ }^{176}$ Some of those creditors who are not professionals, however, have other protections: They may obtain guarantees from insiders, they may insist on prepayment, they may shorten their terms and raise their prices, or they may just choose not to do business with a debtor. ${ }^{177}$ Attorneys and other professionals are not in the same situation. Once an attorney appears in court, he will need leave of court to resign; although his retention order may provide for periodic payments subject to disgorgement pending final allowance of his fees, ${ }^{178}$ he can be subject to considerable holdbacks, he must bill at his normal rates, and his fees are not those that he has negotiated with his client but rather those that are allowed by the court. ${ }^{179}$ Finally, and perhaps as important, he knows to insist upon a carve out to protect against the worst-case scenario. ${ }^{180}$ For that reason, it is common for Chapter 11 cases to provide for a carve out for professionals. ${ }^{181}$ It is to be hoped

approval. Id. $\S 363(\mathrm{c})(2)$. A debtor cannot obtain a secured loan without court approval. Id. $\S$ 362(c).

171. See Levin, supra note 167 , at $447-48$.

172. See generally id.

173. Id. at 456-57.

174. See, e.g., In re White Glove, Inc. No. 98-12493 DWS, 1998 WL 731611, at *23 (Bankr. E.D. Pa. 1998).

175. See Levin, supra note 167 , at 449-55.

176. See id. at 448-49.

177. See generally Levin, supra note 167.

178. See 11 U.S.C. $\S 331$ (2012).

179. See generally id. $\S 330$.

180. See In re Ames Dep't Stores, Inc., 115 B.R. 34, 38 (Bankr. S.D.N.Y. 1990) (“[I]t has been the uniform practice in this Court ... to insist on a carve out from a super-priority status and post-petition lien in a reasonable amount . . . to preserve the adversary system. Absent such protection, the collective rights and expectations of all parties-in-interest are sorely prejudiced.").

181. See, e.g., In re Hotel Syracuse, Inc., 275 BR. 679, 682-83 (Bankr. N.D.N.Y. 2002) 
that the carve out functions merely as an insurance policy for the professionals; in a case in which a plan is confirmed, all administrative creditors must be paid in full, in cash, on the plan's effective date, unless they agree to different treatment. ${ }^{182}$ Thus, even though the special carve out for professionals may have to be called on in theory, the situation in which it is most likely to become relevant is in an administratively insolvent case, which is a candidate for a conversion or dismissal. ${ }^{183}$ Because the payments are made from the secured creditor's collateral and voluntarily made available by the secured creditor, professionals argue that the Normal Priority Rules are not violated, but without doubt the Equality of Treatment Rule could be violated: The professionals are paid up to the amount of the carve out, but if a Chapter 11 plan is not confirmed and the case is dismissed or converted to a case under Chapter 7, other administrative creditors may go home empty-handed, or, at best, with a much smaller percentage recovery. ${ }^{184}$

\section{Pre-Plan Settlements}

Yet another way in which the Normal Priority and Equality of Treatment Rules are sometimes ignored is through the approval of pre-plan settlements. Under the Bankruptcy Code and Rules, ${ }^{185}$ a court may approve a settlement before a reorganization plan is approved, or, alternately, the plan may include a settlement of disputed issues. ${ }^{186}$

A settlement incorporated into a reorganization plan must comport with the Normal Priority Rules: The Supreme Court in TMT Trailer Ferry held a settlement in a plan must be "fair and equitable," that is, comport with the absolute priority rules. ${ }^{187}$

Courts have not yet resolved, however, whether pre-plan settlements must comply with the fair and equitable rules. The Fifth Circuit Court of Appeals long has taken the approach that pre-plan settlements must be fair and equitable,

(approving a carve out for the benefit of debtors' counsel). But see In re Ben Franklin Retail Stores, Inc., 210 B.R. 315, 316 (Bankr. N.D. Ill. 1997) (holding the Bankruptcy Code does not authorize payment to debtors' attorneys under an agreement with a secured creditor because such an agreement would reorder priorities).

182. See 11 U.S.C. $\$ 1129(a)(9)(A)(2012)$.

183. See id. $\S 1112(\mathrm{~b})(4)$.

184. See generally id. $\S 1112$.

185. Bankruptcy Rule 9019(a) provides, "On motion by the trustee and after notice and a hearing, the court may approve a compromise or settlement." FED. R. BANKR. P. 9019(a). Code $\S$ 363(b) allows the estate to use property "other than in the ordinary course of business." 11 U.S.C. $\S 363$ (b) (2012).

186. 11 U.S.C. $§ 1123$ (b) stipulates that "[s]ubject to subsection (a) of this section, a plan may ... provide for ... the settlement or adjustment of any claim or interest belonging to the debtor or to the estate." 11 U.S.C. $\$ 1123($ b)(3)(A) (2012).

187. Protective Comm. for Indep. Stockholders of TMT Trailer Ferry v. Anderson, 390 U.S. 414, 441 (1968). 
because otherwise interested parties could use the pre-plan approval process to circumvent important safeguards of the Bankruptcy Code. ${ }^{188}$ The Fifth Circuit explained,

As soon as a debtor files a petition for relief, fair and equitable settlement of creditors' claims becomes a goal of the proceedings. The goal does not suddenly appear during the process of approving a plan of compromise. ... [L]ooking only to the fairness of the settlement as between the debtor and the settling claimant contravenes a basic notion of fairness. ${ }^{189}$

By contrast, the Second Circuit Court of Appeals has indicated a court could approve a settlement that did not comport with the Normal Priority Rules, provided that the settlement "was 'a step towards possible confirmation of a plan of reorganization and not an evasion of the plan confirmation process." 190 Indeed, the Second Circuit emphasized that "in the Chapter 11 context, whether a pre-plan settlement's distribution plan complies with the Bankruptcy Code's priority scheme will be the most important factor for a bankruptcy court to consider in approving a settlement under Bankruptcy Rule 9019. In most cases, it will be dispositive." 191 The Second Circuit repeated the importance of the Fair and Equitable Rule in the consideration of settlements when it stressed that " $[t]$ he court must be certain that parties to a settlement have not employed a settlement as a means to avoid the priority strictures of the Bankruptcy Code." ${ }^{192}$

\section{Gifting}

Another important way in which Chapter 11 plans increasingly have eroded the Normal Priority Rules is through the "gifting" doctrine. Under this "gift theory," a secured creditor is allowed to select which inferior creditors receive a payment from the proceeds of its collateral when the secured creditor is not being paid in full. ${ }^{193}$ The theory is that the secured creditor has made a "gift" of a

188. See United States v. AWECO (In re AWECO, Inc.), 725 F.2d 293, 298 (5th Cir. 1984) (holding a court that approves a settlement as part of a reorganization absent reasonable assurance that the settlement accords with the fair and equitable standard has abused its discretion; noting that " $[t]$ he words 'fair and equitable' are terms of art—-they mean that 'senior interests are entitled to full priority over junior ones"”) (citations omitted).

189. Id.

190. See Motorola, Inc. v. Official Comm. of Unsecured Creditors (In re Iridium Operating LLC), 478 F.3d 452, 467 (2d Cir. 2007).

191. Id. at 455 . The importance of a settlement that does not comply with the absolute priority rule being not part of an "evasion of the plan confirmation process" was stated by the panel twice in its decision. See id. at 467. Justice Sotomayor was among the members of the Second Circuit Court of Appeals panel that decided Iridium. Id. at 454.

192. Id. at 464 (emphasis added).

193. See Official Unsecured Creditors' Comm. v. Stern (In re SPM Mfg. Corp.), 984 F.2d 1305,1309 (1st Cir. 1993) (upholding the "gifting" arrangement by which an undersecured creditor agreed to share the proceeds of its collateral with general unsecured creditors) (Chapter 7 case). 
portion of its payout to the lower priority creditor. ${ }^{194}$ In these cases, it is normal for the payment to the lower priority creditor to "jump over" a disfavored creditor with lesser priority to buy peace and confirm a reorganization plan. ${ }^{195}$ Thus, a gifting plan is contrary to the general rule that holders of junior claims or interest may not receive any distribution unless each senior class receives payment in full on their claims or interests. ${ }^{196}$

The gifting theory first came to popularity from a Chapter 7 case that originated in the First Circuit Court of Appeals: Official Unsecured Creditors' Committee v. Stern (In re SPM Manufacturing Corp.). ${ }^{197}$ In SPM, the senior creditor had a blanket lien on the estate's property. ${ }^{198}$ The collateral was sold, but there were not enough proceeds to pay the senior creditor in full. ${ }^{199}$ Before the property was sold, the senior secured creditor had agreed to share some of the sale's proceeds with junior creditors. ${ }^{200}$ The secured creditor had refused, however, to share the proceeds with priority tax creditors. ${ }^{201}$

The First Circuit Court of Appeals upheld this arrangement, stressing that the secured creditor was free to share its collateral with whomever it wished. ${ }^{202}$ Following the $S P M$ decision, gifting became increasingly common. ${ }^{203}$

Yet, more recently, in Dish Network Corp. v. DBSD North America (In re DBSD North America), ${ }^{204}$ the Second Circuit Court of Appeals attacked the gifting exception to the absolute priority rule. There, the reorganization plan provided that shares and warrants would be distributed to the existing shareholders even though a more senior class of creditors had not voted for the plan and would not be paid in full under the plan. ${ }^{205}$ The bankruptcy court had held that this was a proper gifting plan because certain lienholders were

194. See id. at 1313 (reasoning creditors are generally free to do as they wish with proceeds, including share with other creditors).

195. Even though these payments are referred to as "gifts," they may be differently motivated than are many personal gifts.

196. Compare 11 U.S.C. $\S 507$ (2012) (laying out general Normal Priority Rules), with In re SPM Mfg. Corp., 984 F.2d at 1309 (explaining "gifting" arrangement).

197. 984 F.2d at 1305 .

198. Id. at 1310 .

199. Id. at 1312 .

200. Id. at 1308 .

201. $I d$.

202. Id. at $1319-20$.

203. E.g., In re Genesis Health Ventures, Inc., 266 B.R. 591 (Bankr. D. Del. 2001) (senior creditors who were not being paid in full shared a portion of their distributions with junior classes but not with creditors holding punitive damages claims); In re MCorp. Fin. Inc., 160 B.R. 941 (S.D. Tex. 1993) (approving settlement of litigation between secured lender and FDIC that allowed FDIC to obtain distributions that it could not have received under the absolute priority rules). But see In re Sentry Operating Co., 264 B.R. 850 (Bankr. S.D. Tex. 2001) (refusing to approve gift by senior class of creditors to one class of unsecured creditors but not to another class of unsecured creditors).

204. 634 F.3d 79 (2d Cir. 2011).

205. Id. at 88 . 
undersecured, and because the payments were theoretically coming from money those lienholders would have received, the lienholders could make voluntary gifts of some of their distribution to the equity holders. ${ }^{206}$

In evaluating the propriety of the plan, the Second Circuit focused on two key considerations: the plain language of Bankruptcy Code $\S 1129$ (b) and the Supreme Court's repeated support of the absolute priority rule in cases involving the purported New Value exception to the absolute priority rule. ${ }^{207}$ The court concluded that the Code's language literally did not allow gifts to be made as part of a reorganization plan, and thus, the $D B S D$ plan should not have been confirmed. ${ }^{208}$

In its analysis, the Second Circuit acknowledged that there had been a time, in railroad reorganizations, when it was common for senior creditors and equity holders to squeeze out intermediate creditors, justifying those actions on the theory that the priority skipping was necessary to get the job done. ${ }^{209}$ Notwithstanding the attractive arguments for allowing a deal between equity and senior debt in order to enable confirmation of a plan, the Supreme Court had repeatedly blocked such tactics in cases arising under the Bankruptcy Code. ${ }^{210}$ Indeed, the Second Circuit stressed that

[t]hose [railroad] cases dealt with facts much like the facts of this one: an over-leveraged corporation whose undersecured senior lenders agree to give shares to prior shareholders while intermediate lenders receive less than the value of their claim. And it was on the basis of those cases that the Supreme Court developed the absolute priority rule, with the aim of stopping the very sort or transaction that the appellees propose here. ${ }^{211}$

Similarly, in In re Armstrong World Industries, Inc., the debtor appealed the district court's decisions that its gift plan was not confirmable because it violated the absolute priority rule. ${ }^{212}$ The plan provided for the distribution of warrants to the debtor's pre-petition equity holder but did not pay certain objecting unsecured creditors in full. ${ }^{213}$ There were two classes of unsecured creditors, the general unsecured creditors and the personal injury creditors. ${ }^{214}$ If the general unsecured creditors voted against the plan, the warrants were to flow through to the equity holders as a "gift" from personal injury claimants. ${ }^{215}$ The Third Circuit saw this as having been an improper violation of the absolute priority rule and refused to

206. Id. at $87-88$.

207. Id. at 93-100.

208. Id. at 100-01.

209. Id at 94 .

210. Id.

211. Id. at 99 (internal citations omitted).

212. 432 F.3d 507, 510-11 (3d Cir. 2005).

213. Id. at 509 .

214. Id.

215. Id. at 512 (This is an illustration of what is known as a "drop dead" provision: "If you don't vote for the plan, you can just drop dead"). 
confirm the plan even though the more senior class of unsecured creditors that was being deprived of the warrants was entitled to no distribution in any case, given the debtors' assets and liabilities. ${ }^{216}$

More recently, however, the Third Circuit affirmed an order confirming an arrangement in which the undersecured creditor gifted funds to pay certain professional expenses and the claims of certain favored creditors while freezing out a $\$ 24$ million administrative tax claim. ${ }^{217}$ In In re ICL Holding Co., the Third Circuit Court of Appeals distinguished this gift from the Armstrong situation because in In re ICL Holding Co., estate funds were not being used to make the priority-skipping payments; rather, the cash for those payments came directly from the secured creditor, who had credit bid part of its claim to obtain the collateral. $^{218}$

In In re ICL Holding Co., the secured creditor was undersecured and agreed to credit bid approximately ninety percent of its claim ( $\$ 320$ million) for the estate's assets, including the cash proceeds that had arisen from its collateral. ${ }^{219}$ To facilitate the transaction, it agreed to pay the legal and accounting fees of the debtor and the creditors' committee, as well as other wind down cost, by depositing funds in escrow. ${ }^{220}$ Nevertheless, the committee and the federal government (which asserted that the sale would give rise to a roughly \$24 million capital gains tax that was entitled to administrative priority) objected to the sale. ${ }^{221}$ To resolve the committee's objection, the secured lender agreed to deposit $\$ 3.5$ million in trust to be distributed directly to unsecured creditors. ${ }^{222}$ The priority tax claim, however, would not be paid. ${ }^{223}$

The government argued that this was an improper gifting arrangement that violated the priority rules because the $\$ 3.5$ million should be understood to be partial consideration for the sale, and thus, property of the estate. ${ }^{224}$ The government's case was buttressed by the fact that the money going to creditors actually had been described in the asset purchase agreement as being part of the purchase price. ${ }^{225}$ The circuit court recognized it was "true that the secured creditors paid cash to resolve the objections to the sale," but the "money never made it into the estate." 226 The court believed that, rather than characterize the money being paid by the secured creditor as property of the estate, a more appropriate characterization was that it was money that was being paid to

216. Id. at 513 .

217. See generally In re ICL Holding Co., 802 F.3d 547 (3d Cir. 2015).

218. Id. at 555-56.

219. Id. at 549 .

220. Id. at 550 .

221. Id. at 551 .

222. $I d$.

223. Id.

224. Id. at 552-53.

225. Id. at 556 .

226. Id. at 555 . 
facilitate the transaction. ${ }^{227}$ According to the court, because the funds to be paid to the unsecured creditors and professionals were not property of the estate, this transaction was not an improper distribution of estate funds contrary to the priority rules, but a legitimate gift of property of the secured creditor. ${ }^{228}$

1. Comparing Settlements to Gifting.--If the gifting exception to the Normal Priority Rules and the Equality of Treatment Rule seem extremely similar to the settlement exception, it is because they are: There is basically one difference. In the settlement exception, an action has been threatened or brought against one of the settling parties (typically, a secured lender, although it could be another party). ${ }^{229}$ The money that is distributed in contravention of the Normal Priority and Equality of Treatment Rules is described as being paid in settlement of that claim. ${ }^{230}$ By comparison, in the gifting exception to the Normal Priority and Equality of Treatment Rules, no cause of action against the party giving the gift has been threatened publically or commenced against the gifting party. ${ }^{231}$ In theory, the gift is a matter of largess from the secured creditor, made available from its own funds, and not being made to settle a cause of action that belongs to the estate. That distinction, while it may seem somewhat artificial, can be critical to the authorization of gifting distributions because money paid in settlement of claims that have been commenced against a creditor or other entity is property of the estate, ${ }^{232}$ that in a Chapter 11 plan or in a Chapter 7 liquidation would have to be distributed in accordance with the distribution rules. ${ }^{233}$ By contrast, a gift from a secured creditor is not, at least following In re ICL Holding Co., treated as estate property (at least in the Third Circuit), and thus, proponents of gifting argue, not required to be distributed in accordance with the Normal Priority Rules. ${ }^{234}$

2. Looking the Gift Horse in the Mouth.-As noted, the payments of undersecured creditors to junior creditors are characterized as being gifts designed to lead to an efficient resolution of the Chapter 11 process. ${ }^{235}$ But are these payments really gifts? It may be more appropriate to think of them as, at

227. Id. at 557.

228. Id.

229. See FED. R. BANKR. P. 9019(a) (giving courts authority to settlements and requiring notice be provided to creditors, United States Trustee, the debtor, etc.).

230. See In re Armstrong World Indus., Inc., 432 F.3d 507, 515 (3d Cir. 2005) ("settlement of their intercompany claims").

231. See In re SPM Mfg. Corp., 984 F.2d 1305 (1st Cir. 1993) (an early example of a "gifting" settlement between different classes of creditors).

232. See 11 U.S.C. $\S 541(a)(6)$ (2012).

233. See FED. R. BANKR. P. 3021. But see In re TSIC, Inc., 393 B.R. 71, $75-77$ (Bankr. D. Del. 2008) (court approves priority-skipping settlement that distributed funds received from third parties as settlement of estate cause of action as being a "gift" because it was received from the third parties as settlement proceeds and therefore came within the SPM Mfg. gift exception to the absolute priority rule).

234. See generally 802 F.3d 547 (3d Cir. 2015).

235. Id. 
best, having been "regifted." 236 This is because in many cases in which the secured creditors donate gifts to junior creditors, in fact, the estate has already given them a valuable gift. ${ }^{237}$ This gift that the secured creditor has received is referred to as the "506(c) waiver." ${ }^{238}$

Bankruptcy Code $\S 506(\mathrm{c})$ provides:

The trustee may recover from property securing an allowed secured claim the reasonable, necessary costs and expenses of preserving, or disposing of, such property to the extent of any benefit to the holder of such claim, including the payment of all ad valorem property taxes with respect to the property. ${ }^{239}$

Different circuits take a different approach to the section, and some circuits have engrafted into the statute language that Congress chose not to add. Thus, for example, some courts hold that for an expenditure to be charged to a creditor under Code $\S 506(\mathrm{c})$, the expenditure should be primarily for that creditor's benefit. $^{240}$ Other circuits take a view that is more consistent with the language of Code $\S 506(\mathrm{c})$ and hold that even if the estate might have benefitted from expenditures of the estate that preserved or enhanced the collateral's value, the secured creditor can be surcharged. ${ }^{241}$ While it may be in a Chapter 11 case in which a reorganization plan is confirmed that the estate's administrative expenses should not be seen as being sufficiently for the benefit of the secured creditor to hold that creditor liable for those costs, as the ICL Holding circuit court recognized, in many cases a Chapter 11 case is driven by one goal: to liquidate

236. Regifting is when a person receives a present from $\mathrm{X}$ and later gives the gift to $\mathrm{Y}$.

237. See, e.g., InteliQuest Media Corp. v. Miller (In re InteliQuest Media Corp.), 326 B.R. 825, 827 (B.A.P. 10th Cir. 2005).

238. See, e.g., id. at 829.

239. 11 U.S.C. $\S 506(c)$ (2012).

240. General Elec. Credit Corp. v. Peltz (In re Flagstaff Foodservice Corp.), 762 F.2d 10, 12 (2d Cir. 1985) ("The debtor in possession also must show that its funds were expended primarily for the benefit of the creditor and that the creditor directly benefited from the expenditure.") (citing Brookfield Prod. Credit Ass'n v. Borron, 738 F.2d 951, 952 (8th Cir. 1984)); see also United Jersey Bank v. Miller (In re C.S. Associates), 29 F.3d 903, 908 (3d Cir. 1994) (post-petition taxes not for direct benefit of secured creditor and thus could not be recovered from that creditor); In re Parque Forestal, Inc., 949 F.2d 504, 511 (1st Cir. 1991) (trustee or debtor in possession must establish by a preponderance of the evidence that (1) the expenditure was necessary; (2) the amount spent was reasonable; and (3) the expenditure benefitted the secured creditor); In re Trim-X, Inc., 695 F.2d 296, 302 (7th Cir. 1982) (expenditure before trustee moved to abandon property not for the primary benefit of the secured creditor); In re Strategic Labor, Inc., 467 B.R. 11, 22 (Bankr. D. Mass. 2012) (noting expenses of selling property as a going concern may be recovered under Code section 506(c)).

241. E.g., Sw. Sec. FSB v. Segner (In re Domistyle, Inc.), 811 F.3d 691, 698-700 (5th Cir. 2015) (secured creditor can be liable under Code $\S 506(\mathrm{c})$ even though there may have been potential for the estate to also benefit from the expenses to be surcharged). 
the secured creditor's collateral. ${ }^{242}$ The secured creditor benefits from a sophisticated forum, a "free and clear" sale, and a final order that can obviate title issues that may concern a purchaser. If the case stays in Chapter 11, the secured creditor will not have to deal with a pesky Chapter 7 trustee, who has the bad habit of bringing litigation on spec and abandoning assets unless he can be assured of his commission, attorney's fees, and cooperation.

All of these benefits make the Chapter 11 bankruptcy court an attractive liquidation forum. ${ }^{243}$ Therefore, in a case in which liquidation is inevitable and the only entities that are paid other than the secured creditor are the professionals and creditors who receive a small "tip" in exchange for a relatively speedy case, it may be misleading to characterize the secured creditor as giving a gift to any creditor; rather, the secured creditor is paying a small "use" fee for the privilege of using Chapter 11 in lieu of a less attractive state forum. ${ }^{244}$ Indeed, the undersecured creditor's inaction in failing to move to lift the automatic stay to foreclose on its collateral outside of bankruptcy is evidence that the bankruptcy court is where the creditor wants to be in many cases. ${ }^{245}$

\section{Structured Dismissals' Violation of Distribution Rules}

The final way in which Chapter 11 cases sometimes avoid the Normal Priority and Equality of Treatment Rules is in a modern structured dismissal. Before we look at some sample cases however, an important point needs to be made: Figuring out what is going on in these cases is a laborious and difficult task that can be prone to error, either because it is so tough to unravel the facts or because the disclosure is so faulty. Let me explain.

In a Chapter 11 reorganization case, (with very limited exceptions) the plan proponent must supply the creditors with adequate information in the form of a document referred to as a "disclosure statement." ${ }^{246}$ The plan proponent typically does not create this document without potential input from creditors. Indeed, the plan proponent must have its disclosure statement approved by the court as containing adequate information ${ }^{247}$ and usually must give the creditors twentyeight days' notice by mail of the time for filing objections to the disclosure

242. See In re ICL Holding Co., 802 F.3d 547, 557 (3d Cir. 2015).

243. The court in In re ICL Holding Co. noted that a bankruptcy court liquidation had become the "tool of choice" for secured creditors to liquidate their collateral and "avoid[] . . time [and] expense." 802 F.3d at 549.

244. See generally id. at 557.

245. See 11 U.S.C. $\S 362(d)(2)$ (2012). The commencement of a bankruptcy case creates an automatic stay that prohibits a creditor from foreclosing on a debtor's collateral unless the court lifts the automatic stay. Id. $\S 362(\mathrm{a})$. Under Code $\S 362(\mathrm{~d})(2)$, the stay can be lifted with respect to property if the property is not necessary for a reorganization and the debtor does not have equity in the property. Therefore, a structured dismissal case involving an undersecured creditor would be an easy case to have the automatic stay lifted.

246. Id. $\S 1125$.

247. 11 U.S.C. $§ 1125(a)(1)$ (2012) defines "adequate information." 
statement. ${ }^{248}$ This notice is notice of the time to object to the disclosure statement: The hearing will be even later, absent bizarre circumstances. ${ }^{249}$ The disclosure statement can be a lengthy document full of information. ${ }^{250}$ It will often contain a chart showing who gets what. The importance of the disclosure statement is not only that it contains a great deal of information, but it presents that information in one document provided to creditors at the time they need the information to make a decision on the plan. ${ }^{251}$ Should there be any question about whether all the important facts have been presented, this can be addressed at the hearing on the disclosure statement and appropriate modifications can be made to the document. ${ }^{252}$ After the disclosure statement is approved and sent to creditors, the creditors might receive even more information when the plan proponent moves to confirm the plan, again on twenty-eight days' notice of the time to object, ${ }^{253}$ and addresses any objections to the plan. ${ }^{254}$

That is not the case with a structured dismissal Zombie Plan. Although the Zombie Plan functions in many ways as a substitute for a Chapter 11 plan, the structured dismissal is brought on by motion with twenty-one days' notice of the hearing. ${ }^{255}$ While of course the movant has to show cause for the relief requested, in fact these motions are often pretty sparse, basically asserting "the estate is broke;" "there is no other way out;" "the courts are doing this all the time," "you've done this before," and, more recently, "the Third Circuit Court of Appeals has approved a dismissal." I have seen no motion that sets forth all the payments that were made and will be made on claims and administrative expenses. I have seen motions that vaguely refer to other documents (not included with the motion) as setting forth information regarding what distributions will be made either pre- or post-dismissal.

What this means is that one must dig through thousands of docket entries to find documents that might reflect distributions of estate assets in a structured dismissal. Knowing that those distributions may be hidden in a financing motion and order, cash collateral motion and order, critical vendor motion and order, settlement motion and order, or Code $\S 363$ (b) motion and order helps, but does not necessarily create certainty. Accordingly, understanding who is being paid what, is really tough and time-consuming in the structured dismissal context, and more importantly, subject to error in the best of circumstances. Even when a

248. FED. R. BANKR. P. 2002(b).

249. Neither the plan proponent nor the court wants to receive any disclosure statement objections on the date of the hearing and wise counsel will want plenty of time before the disclosure statement hearing to negotiate appropriate revisions to the disclosure statement, or, failing that, to categorize unresolved objections and brief the court regarding why those objections should be overruled.

250. See generally FED. R. BANKR. P. 2002(b).

251. See id.; 11 U.S.C. $\S 1125$ (2012).

252. 11 U.S.C. $\S 1125$ (2012).

253. FED. R. BANKR. P. 2002(b).

254. Id.

255. FED. R. BANKR. P. 2002(a)(4). 
sophisticated appellate court such as the Third Circuit summarizes the facts from a presumably fine record, information can be missing or unclear. ${ }^{256}$

That being understood, the most well-known example of a modern structured dismissal that violates the Normal Priority Rules and Equality of Treatment Rules in a structured dismissal is the Jevic case, in which priority claims of employees went unpaid while more junior unsecured creditors were paid roughly four percent on their claims. ${ }^{257}$ The Third Circuit Court of Appeals approved this dismissal - which it indicated three times should be a "rare case"-because it believed it was the best of bad alternatives. ${ }^{258}$

Here are the facts: Jevic Transportation, Inc. was a trucking company. ${ }^{259}$ In 2006 (after Jevic's business had begun to decline), Jevic was purchased by an affiliate of the private equity group, Sun Capital Partners, with financing provided by a facility of lenders ("CIT") arranged by CIT Group. ${ }^{260}$ The deal was structured as a leveraged buyout ("LBO"); Jevic's assets were pledged to CIT to enable Sun to acquire the company. ${ }^{261}$

By May, 2008, less than two years after the LBO closed, Jevic was in great financial stress. ${ }^{262}$ Apparently left with no alternatives, Jevic filed for bankruptcy, without providing its workers the requisite sixty-day WARN notice. ${ }^{263}$ Jevic terminated a large number of drivers the day before filing for Chapter 11 relief. $^{264}$ Once Jevic entered bankruptcy, it became embroiled in litigation on two fronts. First, the fired employees brought WARN Act claims against the debtor, and against the private equity owners of Jevic. ${ }^{265}$ In addition, the Jevic creditors' committee brought a fraudulent transfer action against Sun and CIT, ${ }^{266}$ alleging that Sun, with CIT's aid, had "acquired Jevic with virtually none of its own money based on baseless projections of almost immediate growth and increasing

256. Official Comm. of Unsecured Creditors v. CIT Grp./Bus. Credit Inc. (In re Jevic Holding Corp.), 787 F.3d 173, 177, 185 (3d Cir. 2015) (ambiguity as to whether workers were paid on their unsecured claims in the same proportion as other unsecured creditors).

257. Although it is not $100 \%$ clear from the decision, it appears that unsecured claims of certain creditors (the drivers) were not paid while other unsecured claims of equal priority were paid. $I d$. at 179,185 . This would mean that not only was the 507 priority rule violated, but in addition, the Equality of Treatment Rule was violated.

258. Id. at 186.

259. Id. at 175 .

260. Id.

261. Id.

262. Id. at 175 .

263. See 29 U.S.C. § 2102 (2012); N.J. STAT. ANN. § 34:21-2 (2016).

264. In re Jevic Holding Corp., 787 F.3d at 176. Jevic had terminated 1800 drivers. Kat Greene, 3rd Circ. Won't Rehear Drivers' Bid for Priority in Ch. 11 Deal, LAw 360 (Nov. 11, 2016), http://www.law360.com/articles/692568/3rd-circ-won-t-rehear-drivers-bid-for-priority-inch-11-deal [https://perma.cc/823R-NPYG].

265. In re Jevic Holding Corp., 787 F.3d at 176.

266. $I d$. 
profitability.",267

The fired employees eventually prevailed on their state law WARN Act claims against the debtor, ${ }^{268}$ but not against Sun, because the court held that Sun was not an "employer" as defined in the relevant statutes. ${ }^{269}$ Courts in the Third Circuit have consistently held that certain pre-petition WARN Act claims are entitled to priority. ${ }^{270}$ The drivers claimed to have an $\$ 8.3$ million fourth priority WARN Act claim and a $\$ 4.1$ million general unsecured claim arising out of their WARN Act claims. ${ }^{271}$

Creditors in the fraudulent conveyance action were also busy litigating issues: Although CIT's motion to dismiss was granted in part, both Sun and CIT remained as defendants in the litigation after their dismissal motions failed in part. $^{272}$

Eventually, in 2012, the creditors' committee, Sun, and CIT reached a compromise that contemplated a dismissal of the Chapter 11 case. $^{273}$ The settlement required CIT to set aside $\$ 2$ million to pay the legal expenses of the committee and to pay other administrative expenses. ${ }^{274}$ The creditors' committee, equity, and the lender agreed that the drivers would receive absolutely nothing. ${ }^{275}$ Instead, more junior creditors - unsecured creditors - would be paid in part out of a $\$ 1.7$ million pot. ${ }^{276}$ Initially, that $\$ 1.7$ million was earmarked solely for the unsecured creditors, but after taxing authorities objected, much of it went to pay priority tax claims. ${ }^{277}$ The drivers also objected, but their objections were overruled, even though their claims, like those of the taxing authorities, were entitled to priority. ${ }^{278}$

Why were the drivers frozen out? Apparently, they were frozen out to protect equity. ${ }^{279}$ Suns' counsel explained:

You can take judicial notice that there's a pending WARN action against Sun by the WARN Plaintiffs. And if the money goes to the WARN Act Plaintiffs, then [Sun would be] funding somebody who is suing you who

267. Id.

268. Czyzewksi v. Jevic Transp. Inc. (In re Jevic Holding Corp.), 496 B.R. 151, 165 (Bankr. D. Del. 2013).

269. Czyzewski v. Sun Capital Partners, Inc. (In re Jevic Holding Corp.), 526 B.R. 547, 556 (D. Del. 2014).

270. In re Jevic Holding Corp., 787 F.3d at 177 (citing In re Powermate Holding Corp., 394 B.R. 765, 773 (Bankr. D. Del. 2008)).

271. Id.

272. Id. at 176.

273. Id. at 177.

274. Id.

275. Id. at 178 .

276. Unsecured creditors eventually received roughly $4 \%$ on their claims. Id. at $177 \mathrm{n} .1$.

277. Id. at 177 .

278. Id. at 178 .

279. Id. 
otherwise doesn't have funds and is doing it on a contingent fee basis. ${ }^{280}$

So, what bankruptcy principles were violated here? One that was clearly violated was that the settlement "priority skipped" and bypassed priority creditors, whom lawmakers had determined to protect. ${ }^{281}$ The legal rationale for this was the case law from the Second Circuit-Iridium - which held that in some cases a pre-plan settlement can vary from the absolute priority rule. ${ }^{282}$ That case, however, is little support for the Jevic priority violation because, twice, the Second Circuit Court of Appeals stressed that "[t]he court must be certain that parties to a settlement have not employed a settlement as a means to avoid the priority strictures of the Bankruptcy Code." ${ }^{283}$ Here, counsel for the equity holders had admitted that avoiding the Code's priority structure was exactly their goal. ${ }^{284}$

In affirming the structured dismissal order, the Third Circuit put great stress on the fact that, given the absence of money in the estate, there was little likelihood of any recovery for any creditors from the fraudulent transfer litigation because both Sun and CIT were well-funded. ${ }^{285}$

The Third Circuit also justified its decision by making a legal error. Perhaps the greatest legal impediment to its reasoning in Jevic was the plain language of Code $\S \S 507$ and 103(a). ${ }^{286}$ Code $\S 507$ has no exceptions to its priority requirements (which include the WARN Act claims), and Code $\S 103(\mathrm{a})$ flatly provides that Code $\S 507$ applies in Chapter 11 cases. ${ }^{287}$ Therefore, the Third Circuit faced language that unambiguously prohibited the Jevic distributions.

In an attempt to explain how its decision would be consistent with the Code's plain language, the Third Circuit stated:

If $\S 103$ (a) means that all distributions in Chapter 11 cases must comply with the priorities of $\S 507$, there would have been no need for Congress to codify the absolute priority rule specifically in the plan confirmation context. ${ }^{288}$

This reasoning is flawed because Code $\S 507$ only addresses priority claims. ${ }^{289}$ The priority claims set forth in Code $\S 507$ are not the claims and

280. Id. at 186 .

281. Id. at 183 .

282. In re Iridium Operating LLC, 478 F.3d 452, 464 (2d Cir. 2007).

283. Id. (emphasis added).

284. Id. at 280 .

285. In re Jevic Holding Corp., 787 F.3d at 179.

286. See U.S.C. $\S 103$ (a) (2012); id. $\S 507$. Code $\S 507$ provides "[t]he following expenses have priority in the following order ... [employee benefit claims, which include the WARN Act claims]. Code $\S 103$ (a) provides that, with exceptions not relevant here, "chapter[] . . 5 of this title appl[ies] in a case under chapter . . 11 . . of this title."

287. Id.

288. In re Jevic Holding Corp., 787 F.3d at 182 n.7.

289. 11 U.S.C. $§ 507$ (2012). 
interests addressed in Code $\S 1129(\mathrm{~b})$, which addresses secured claims, unsecured claims, and interests, but not the priority claims addressed in Code $\S 507 .^{290}$ Therefore, Code $\S \S 507$ and 1129(b) serve totally different purposes, and thus, Code $\S 1129$ (b) does not undermine the conclusion that Congress meant what it promulgated in Code $\S 103(\mathrm{a})$ : The priorities of Code $\S 507$ apply in all cases. ${ }^{291}$ Indeed, where Chapter 11 does address the Code $\S 507$ priorities in the plan context — in Code $\S 1129(\mathrm{a})(9)$ — it does so only to emphasize their importance by making it clear that, absent consent, these claims must be paid in full, in cash, on the effective date of a reorganization plan. ${ }^{292}$

Jevic is not the only structured dismissal case, however, that circumvents the Normal Priority Rules or the Equality of Treatment Rule. The 2015 case In re ICL Holding Co. ${ }^{293}$ case, argued before the Third Circuit on the same day that In re Jevic was argued, was also a structured dismissal case featuring "rare" priority skipping, although the court never recognizes that fact in its opinion. ${ }^{294}$

In In re ICL Holding Co., the secured creditor had agreed to pay legal and accounting fees of the debtor and the creditors' committee and the estate's wind down expenses: ${ }^{295}$ The budget described by the Third Circuit leaves nothing for other administrative expenses or other priority claims, which would have been required to be paid in full in the Chapter 11 case to confirm a liquidating plan. ${ }^{296}$ Thus, it seems clear that no one contemplated a Chapter 11 plan from the very beginning of the case. In any event, after receiving objections to the budget from the government and the creditors' committee, the secured creditor escrowed $\$ 3.5$ million to pay unsecured creditors, but provided nothing for the Code $\S 507$ priority tax claim of the government, which claim (arising from capital gains), the government estimated to be $\$ 24$ million. ${ }^{297}$ The Third Circuit approved this arrangement because it believed the money the secured creditor put into escrow to pay unsecured claims was not property of the estate, and therefore, was not property of the estate. ${ }^{298}$

The circuit court's decision, however, does not reflect what had already occurred in the bankruptcy court: Even before the Third Circuit Court of Appeals heard this gifting appeal, the bankruptcy court had entered an order dismissing the cases (conditioned upon certification of counsel that claims had been paid and the appeal had been resolved). ${ }^{299}$ In short, Jevic is not the only time that the Third Circuit blessed a structured dismissal with a violation of the Normal Priority

290. Id. § 507; id. § 1129(b).

291. See generally id. § 507; id. § 1129(b); id. § 103(a).

292. Id. § 1129(b)(9).

293. 802 F.3d 547, 550 (3d Cir. 2015).

294. See generally id.; In re Jevic Holding Corp., 787 F.3d 173.

295. 802 F.3d at 550.

296. 11 U.S.C. $\S 1129$ (b)(9) (2012).

297. In re ICL Holding Co., 802 F.3d at 551.

298. Id. at 557.

299. See generally id. 
Rules. ${ }^{300}$ In Jevic, the priority skipping was characterized as a settlement; in In re ICL Holding Co., the priority skipping was characterized as a gift. ${ }^{301}$ In both cases, claims that were entitled to priority went unpaid while lower-priority claimholders received a distribution. ${ }^{302}$ Moreover, in In re ICL Holding Co., administrative creditors were treated differently, violating the Equality of Treatment Rule: Although the debtor's and the creditors' committee's professionals were paid, the government's administrative claim for capital gains taxes was unpaid. ${ }^{303}$ In short, every violation of the normal distribution rules that is attacked in the Jevic case pending before the Supreme Court was present in In re ICL Holding Co. ${ }^{304}$

Another reported case that involved a priority-skipping settlement was In re TSIC, Inc. ${ }^{305}$ TSCI (Sharper Image) filed for bankruptcy after it encountered problems in litigation, and arranged a quick sale to two companies that specialize in liquidations. ${ }^{306}$ The creditors' committee indicated it would object to the sale, and eventually settled with the liquidators. ${ }^{307}$ The settlement specifically provided, however, that the proceeds of the litigation were to go to the unsecured creditors, bypassing senior creditors, which would remain unpaid. ${ }^{308}$

The Office of the United States Trustee (the UST) objected to the motion to approve the settlement, arguing that it violated the absolute priority rule. ${ }^{309} \mathrm{In}$ particular, the UST relied upon the Third Circuit's decision in In re Armstrong, ${ }^{310}$ described above, in which the circuit court had held that a reorganization plan was an impermissible violation of the absolute priority rule when it redistributed warrants from an unsecured class to equity in certain circumstances, even though the unsecured class would not have been entitled to the warrants based upon the valuation of the debtor. ${ }^{311}$ The bankruptcy court rejected the UST's arguments, however, reasoning that the absolute priority rule only applies to the confirmation of reorganization plans. ${ }^{312}$ Here, no reorganization plan was being confirmed, and

300. Order Granting Debtors' Motion for Entry of an Order Pursuant to 11 U.S.C. $\S \S 105(a)$, 305(a), 349, and 1112(b) and Fed. R. Bankr. P. 1017(a) (A) Dismissing the Debtors' Chapter 11 Cases and (B) Granting Related Relief, In re ICL Holding Co., Case No. 12-13319 (KG) (Bankr. D. Del. Jan. 24, 2014), ECF No. 1137.

301. In re ICL Holding Co., 802 F.3d at 557 n.6.

302. See generally id. at 547; In re Jevic Holding Corp., 787 F.3d 173 (3d Cir. 2015).

303. 802 F.3d at 555.

304. Accordingly, if the Supreme Court holds that the In re Jevic structured dismissal is unlawful because settlements must comply with the Code's priority scheme, practitioners might still seek to dismiss cases using the "gifting exception," depending on the decision's language.

305. 393 B.R. 71 (Bankr. D. Del. 2008).

306. Id. at 74 .

307. $I d$.

308. Id.

309. Id. at 76 .

310. 432 F.3d 507 (3d Cir. 2005).

311. In re TSIC, Inc., 393 B.R. at 75 (citing In re Armstrong, 432 F.3d at 518).

312. Id. (citing In re Armstrong, 432 F.3d 507). 
thus the Armstrong case was not controlling. ${ }^{313}$

In reaching its conclusions, the court crafted a broad expansion of the gifting doctrine to hold that the settlement was permitted notwithstanding its alleged violation of priority rules. ${ }^{314}$ Looking to cases such as $S P M^{315}$ and its progeny, in which a priority-skipping "gift" from a secured creditor had been allowed as not having involved estate property, the court reasoned that the Sharper Image settlement proceeds also were not estate property and thus were akin to a permissible priority skipping "gift". ${ }^{316}$ Specifically, the court reasoned that the money being paid for distribution to unsecured creditors was being paid by the purchasers out of their own property to settle a cause of action asserted by the creditors' committee and thus was a "gift" from the purchasers. ${ }^{317}$ The court explained:

Here, unlike Armstrong, the money to be paid to the Committee on behalf of general, unsecured creditors, is non-estate property. The Joint Venture's funds are not proceeds from a secured creditor's lien, do not belong to the estate, and will not become part of the estate even if the Court does not approve the Settlement. In addition, unlike Armstrong, there is no intervening creditor who objects to the Settlement. Neither the Debtor nor any creditor has objected to the Settlement. ${ }^{318}$

The court does note in passing that the Sharper Image settlement is not being incorporated into a reorganization plan. Indeed, the Sharper Image docket reflects that the case was dismissed under a structured dismissal order that provided for, among other things, a novel claims resolution procedure that shifted the burden of proof and excepted from its application local rules relating to objections to claims. ${ }^{319}$ In short, Sharper Image is another "rare" priority skipping

313. Id.

314. Id. at 75-77.

315. In re SPM Mfg. Corp., 984 F.2d 1305 (1st Cir. 1983).

316. In re TSIC, Inc., 393 B.R. at 75-77 (citing In re SPM Mfg. Corp., 984 F.2d 1305; In re PSA Successor Corp., No. 04-13030 (Bankr. D. Del. 2004); In re Armstrong, 432 F.3d 507).

317. Id. at 77.

318. Id.

319. Order Granting Joint Motion of the Debtor and the Official Committee of Unsecured Creditors, Pursuant to Sections 105(a), 305(a), and 112(b) of the Bankruptcy Code, for Entry of An Order (1) Approving Procedures for (A) The Dismissal of the Debtor's Chapter 11 Case, (B) the Distribution of Certain Funds to Holders of Certain Gift Card Claims and (II) Granting Certain Related Relief, In re TSIC, Inc., No. 08-10322 (Bankr. D. Del. Aug. 8. 2012), ECF No. 1520. Other unreported cases I reviewed also were dismissed via a "structured dismissal order" that provided for priority skipping. See, e.g., Order Pursuant to 11 U.S.C. § 105(a), 349 and 305(a) and Bankruptcy Rule 1017(a) (A) Approving Trust Agreements, (B) Authorizing the Transfer of Remaining Assets to the Lender Trustee, (C) Dismissing the Debtors' Chapter 11 Cases and (D) Granting Related Relief, In re Coach Holdings Corp., No. 12-10010 (Bankr. D. Del. May 31, 2013), ECF No. 1568 (providing for, among other things, a \$1,950,000 "carve-out" for unsecured creditors); Order Granting Motion to Dismiss Chapter 11 Bankruptcy Case of Harvey Electronics, 
settlement structured dismissal.

Yet another "rare" case that violates the usual distribution rules is In re Petersburgh Regency $L L C{ }^{320}$ There, a hotel property was wiped out in a hurricane, and the debtor eventually recovered slightly more than $\$ 10$ million. ${ }^{321}$ After forum shopping and procedural wrangling, the case ended up in bankruptcy court in New Jersey. ${ }^{322}$ Eventually, the creditors negotiated a structured dismissal. ${ }^{323}$ Initially, the settlement was designed to skip over priority claimants, including taxing authorities. ${ }^{324}$ After protests and further negotiations, all creditors were to receive distributions, except for the insider creditors. ${ }^{325}$ The decision gives no explanation (except for the brief observation that the disfavored creditors were insiders and their debts might be subordinated or recharacterized $^{326}$ ) for their disparate treatment: The business apparently had failed because of a hurricane. ${ }^{327}$ Nothing in the case indicates that the insiders were lax in protecting the property, negligent in seeking the insurance proceeds, or proved that the obligations from the company should be recharacterized as equity contributions. ${ }^{328}$ Given the total absence of proof justifying their inferior treatment, it is appropriate to characterize this case as one that violates the Equality of Treatment Rules. Of course, there could have been facts that justified this distribution, but in a Chapter 11 case those facts would have had to have been established in an adversary proceeding.

In re Jevic, In re ICL Holding Co., Sharper Image, and In re Petersburgh Regency are reported cases, and therefore, the manner in which they have violated the normal Chapter 11 distribution rules has been summarized from the complex record. In unreported cases, however, it is much more difficult to determine the extent to which there is a violation of the normal Chapter 11 distribution rules.

A case on point is KB Toys, Inc. ${ }^{329}$ The KB Toys cases that resulted in a structured dismissal were what is known in bankruptcy jargon as a Chapter 22 . KB Toys had confirmed a Chapter 11 plan that failed, ${ }^{330}$ and subsequently filed a case that was designed to be centered around a quick going out of business sale

Inc. Pursuant to Section 1112(b) of the Bankruptcy Code and to Authorize Distribution of Carveout Funds to General Unsecured Creditors, In re Harvey Elecs., Inc., No. 07-14051 (Bankr. S.D.N.Y. Dec. 16, 2007), ECF No.177 (providing for distribution of carveout funds to unsecured creditors through a general unsecured creditors trust).

320. 540 B.R. 508 (Bankr. D. N.J. 2015).

321. Id. at 512 .

322. Id. at 513 .

323. Id. at 517 .

324. Id. at 545 .

325. Id.

326. Of course, that determination would have to have been made in an adversary proceeding. FED. R. BANKR. P. 7001.

327. In re Petersburgh, 540 B.R. 508 at 513.

328. See generally id.

329. No. 08-13269 (KJC) (Bankr. D. Del. filed Dec. 11, 2008).

330. In re KB Toys, Inc., No. 04-10120 (KJC) (Bankr. D. Del. filed Jan. 14, 2004). 
and a structured dismissal. ${ }^{331}$ The court did not enter a financing order; rather it approved a cash collateral order that waived the estate's 506(c) claims and granted a carve out for U.S. Trustee fees and for roughly $\$ 3$ million for unpaid professional fees. ${ }^{332}$

After the KB Toys assets were disposed of, there remained various unpaid administrative creditors: 503(b)(9) claimants (creditors whose goods had been received by the debtor within twenty days of the bankruptcy filing) and "Stub Rent" payments (rent for the period the property was used by the debtor after its petition was filed). ${ }^{333}$ The compromise that was the cornerstone of the dismissal was to pay the Stub Rent claimants a roughly seventy-five percent recovery and the 503(b)(9) claimants a roughly fifty-seven percent recovery. ${ }^{334}$ Although the justification for the disparate treatment was not entirely clear, the motion to approve the compromise noted that parties might assert that the Code $\S 503(\mathrm{~b})(9)$ claimants had received some preferential payments. ${ }^{335}$ This explanation for the violation of the Equality of Treatment Rule was only mentioned briefly. ${ }^{336}$ If there was any priority jumping in the settlement, it was not obvious from the pleadings.

\section{CONCLUSion: The CHAPTER 11 Zombie APOCAlypse}

The purpose of this Article was to determine if the Jevic structured dismissal was in fact a rare case in violating the normal distribution rules of the Bankruptcy Code by taking a preliminary look at structured dismissal cases. Although this is only a preliminary investigation, Jevic may not be so rare. At the same time the

331. In re KB Toys, Inc., No. 08-13269 (KJC) (Bankr. D. Del. filed Dec. 11, 2008).

332. Id.

333. See SDNY Weighs in on "Stub Rent," ABSOlute PRIORITY (Cooley Godward Kronish LLP, New York, N.Y.), Spring 2009, at 4, http://bankruptcy.cooley.com/wp-content/uploads/ sites/245/2009/04/Absolute-Priority-Spring-2009.pdf [https://perma.cc/WDT3-LFZR].

334. Order Granting Joint Motion of the Debtors and the Official Committee of Unsecured Creditors, Pursuant to Sections 105(a), 305(a), 349 and 1112(b) of the Bankruptcy Code and Rule 9019 of the Federal Rules of Bankruptcy Procedure, for Entry of an Order (A) Approving a Stipulation Between the Debtors, the Committee, and the Prentice Entities, (B) Approving (I) the Distribution of Certain Funds to Holders of Allowed Administrative Claims, and (II) the Dismissal of Debtors' Chapter 11 Cases, and (C) Granting Certain Related Relief, In re KB Toys, Inc., 470 B.R. 331, No. 08-13269 (Bankr. D. Del. Dec. 1, 2009), ECF No. 914; Joint Motion of the Debtors and the Official Committee of Unsecured Creditors, Pursuant to Sections 105(a), 305(a), 349, and 1112(b) of the Bankruptcy Code and Rule 9019 of the Federal Rules of Bankruptcy Procedure, for Entry of an Order (A) Approving a Stipulation Between the Debtors, the Committee and the Prentice Entities, (B) Approving Procedures for (I) the Distribution of Certain Funds to Holders of Allowed Administrative Claims and (II) the Dismissal of the Debtors' Chapter 11 Cases, and (C) Granting Certain Related Relief, In re KB Toys, Inc. 470 B.R. 331, No. 08-13269 (KJC) (Bankr. D. Del. Nov. 9. 2009), ECF No. 872 (“KB Toys Dismissal Motion”) ๆ 35 (noting estimated percentage distributions to various claimholders).

335. KB Toys Dismissal Motion, $₫ 33$.

336. $I d$. 
Third Circuit was deciding In re Jevic, it was deciding another structured dismissal case (In re ICL Holding Co.) that violated both the Normal Priority Rules and the Equality of Treatment Rule. ${ }^{337}$ The Third Circuit did not mention that the case was designed to be dismissed from its inception, although that is exactly what happened and could easily be inferred from the deal that was cut from the inception of the case. ${ }^{338}$ This, as well as the other structured dismissal cases we have looked at, suggest that the violation of the usual distribution rules we see in Jevic may not be so rare. ${ }^{339}$ Indeed, one highly-regarded former judge in the Delaware Bankruptcy Court noted that

[o]ver the course of the last five years or so, I have seen a number of liquidating chapter 11 cases in this Court where the official committee of unsecured creditors entered into this type of carve out settlement [that skipped priority creditors] . . . for the benefit of general unsecured creditors. Similar to the instant situation, those cases involved asset sales with little or no prospects for any recovery therefrom for general unsecured creditors. ${ }^{340}$

Indeed, if the Supreme Court affirms the dismissal order in Jevic, it is hard to imagine that we will not face a Zombie Plan apocalypse.

Proponents of the Zombie Plan bankruptcy resolution may argue that the speed, flexibility, and creativity of the process encourages secured lending by enhancing recoveries for secured creditors, minimizing administrative expenses, encouraging sophisticated restructuring counsel to shepherd the liquidation, and preserving asset value by giving priority to those creditors whose payment will enhance the value of the lender's collateral. ${ }^{341}$ Fulfilling an obligation to pay WARN Act claims or tax claims does not, some might argue, encourage private equity to take risks or secured creditors to make loans. Indeed, the taxing authorities or truck drivers may not be particularly sympathetic creditors.

Imagine instead, an individual Chapter 11 case where the priority claimant is a child maimed by a cocaine-addled driver. ${ }^{342}$ Imagine further that the debtor had a vast estate, ${ }^{343}$ subject to the security interest of an undersecured creditor. Rather than distribute the proceeds of the sale in accordance with the Code $\S 507$ priorities, the debtor structured a sale in which his lawyers and accountants were paid, his jewelers and their lawyers were paid, but the maimed child received nothing. The deal was justified because it was the only deal to which the secured

337. See supra Part V.

338. See supra Part V.

339. See supra Part V.

340. In re World Health Alternatives, Inc., 344 B.R. 291, 297 n.3 (Bankr. D. Del 2006).

341. See supra Part V.

342. Of course, the claim would not be dischargeable, 11 U.S.C. § 523(a)(9) (2012) (excepting from discharge claims "for ... personal injury caused by the debtor's operation of a motor vehicle ... if such operation was unlawful because the debtor was intoxicated from . . a drug"), but who wants to try to recover money from a drug addict?

343. You may want to imagine also that the debtor is a former celebrity or actor. 
creditor and the creditors' committee would agree, and it was better than nothing. Alternately, imagine that the brilliant lawyers structured the purchase so that the creditor placed funds in escrow or trust to pay favored pre-petition vendors to obviate their objections to the sale, but the maimed victim again received nothing. Because the money set aside was not estate property, the court held that distribution structure to be appropriate. Perhaps in such a situation, the disregard of the 507 Priority Rule might seem more questionable than it did to the Third Circuit Court of Appeals in In re Jevic and In re ICL Holding Co. ${ }^{344}$

What we have seen in this preliminary look at structured dismissals is that they are not rare, nor are provisions in such dismissals that violate the Normal Priority Rules or the Equality of Treatment Rule rare. ${ }^{345}$ Granted, some of the violations of the Normal Priority and Equality of Treatment Rules also occur in regular Chapter 11 cases: The carve out is "market" in large cases, the "critical vendor order" is not unusual, and other creative classification issues could lead to disparate treatment of creditors. ${ }^{346}$ That being said, the obligation to pay administrative and priority creditors when a Chapter 11 case is confirmed can only be waived by the claim holder. ${ }^{347}$ Moreover, when appellate courts have approved any tinkering with the Normal Priority Rules or the Equality of Treatment Rule ${ }^{348}$ they have done so because those variations are necessary for a reorganization plan. Thus, for example, the critical vendor order may be permitted in Chapter 11 cases because it will facilitate a reorganization plan, not because it will enhance the recovery to the secured creditor. ${ }^{349}$ Previously, when a pre-plan settlement has been approved that may violate the Fair and Equitable Rule, it was justified only because it was a step to a reorganization plan and only when the court could be certain that it was not designed to disadvantage priority creditors. ${ }^{350}$ Neither of those rationales works in the case of a structured dismissal.

But what about the larger question of whether we can justify departing from the Normal Priority and Equality of Treatment Rules to allow secured creditors to save money and recover more on their collateral? I suggest not. No one has proven that capital will be more available if we allow Zombie Plans to flourish. Even if they did, there is the matter of basic fairness and adherence to the plain language of Code section 507. The drivers that went unpaid in Jevic ${ }^{351}$ made money for the creditor to the end, and New Jersey has made a decision that they have a right to a special severance-type pay. ${ }^{352}$ Congress decided this obligation

344. See supra Part V.

345. See supra Part V.

346. See supra Part IV.

347. I.e., 11 U.S.C. $§ 1129(a)(9)$ (2012) (requiring full payment of administrative and priority claims absent waiver by the claimholder).

348. These Equality of Treatment Rules are, as noted, a bit more flexible than the Normal Priority Rules.

349. See generally In re Kmart Corp., 359 F.3d 866 (7th Cir. 2004).

350. In re Iridium Operating LLC, 478 F.3d 452, 464 (2d Cir. 2007).

351. See generally In re Jevic Holding Corp., 787 F.3d 173 (3d Cir. 2015).

352. Id. at 185 . 
has priority. ${ }^{353}$ The federal government that was seeking its capital gains tax in In re ICL Holding Co. ${ }^{354}$ was the same government that was paying for the outstanding bankruptcy court, district court, and the Third Circuit Court of Appeals that the secured creditor was using to realize the maximum value on its collateral. ${ }^{355}$ Congress decided that claim, too, was entitled to priority. ${ }^{356}$

Indeed, the secured creditor should have had to pay to play: Congress already determined that in Code $\S 506(\mathrm{c}) .{ }^{357}$ At the least, the secured creditor must be liable for the reasonable costs of administration of a Chapter 11 case if it wants to use Chapter 11 to liquidate its collateral. At the least, the secured creditor should not be able to throw a bone to junior creditors to walk away from more substantial liability. This does not mean all structured dismissals should be barred. The Code contemplates such a dismissal in Code $\S 349$. But when sophisticated creditors learn they can avoid a meddlesome Chapter 7 trustee, a bothersome taxing authority, and get away with wage theft by paying some professional fees, paying a small amount to unsecured creditors, and carefully structuring the deal, why would they not choose this route if they were undersecured? That is the type of incentive that leads to a dangerous Zombie Plan apocalypse. The Third Circuit- the court deciding appeals from the District of Delaware, in which most large Chapter 11 cases are filed ${ }^{358}$ - has set these creatures loose. In the Zombie Plan apocalypse workers will get stiffed, taxes will be unpaid, and the Bankruptcy Code will be distorted. Warning: don't look out the window.

353. $I d$. at 183 .

354. 802 F.3d 547, 550 (3d Cir. 2015).

355. $I d$.

356. $I d$.

357. See generally, FSB v. Segner (In re Domistyle, Inc.), 811 F.3d 691, 696-700 (5th Cir. 2015) (expenses incurred by a trustee in maintaining property before moving to abandon the property should be charged to the secured creditor). Congress also provided in Code $\S 552$ that the secured creditor's security interest in proceeds could be cut off in accordance with the "equities of the case." 11 U.S.C. $\S 552(b)(1)$ (2012).

358. Jared A. Wilkerson, Defending the Current State of Section 363 Sales, 86 Am. BANKR. L.J. 591, 599 (2012) (compiling data for filings of large Chapter 11 cases [cases with over $\$ 100$ million in assets in 1980 dollars] during period from 1982 to 2011; Delaware had eighty-two percent of such filings between 2008 and 2011). Apparently many of these cases result in dismissals: One scholar's investigation of filings in the District of Delaware in 2006 concluded that "[o]ver sixty-five percentage of the Delaware cases had sales and most of them appeared to be substantial-i.e., liquidating." Westbrook, supra note 27 at 843. 